\title{
Growth Factor Mediated Regulation of Beta Cell Survival
}

\author{
Nagesha Guthalu Kondegowda, Xiaoying Zhang, Katoura Williams, Anaïs Mozar and \\ Rupangi C. Vasavada*
}

Division of Endocrinology, Department of Medicine, University of Pittsburgh, Pittsburgh, PA 15261, USA

\begin{abstract}
Numerous studies have shown that a reduction in the endogenous functional $\beta$-cell mass is a major cause of every form of diabetes. Therefore, the development of therapies to preserve and regenerate endogenous $\beta$-cell mass and function holds great promise for both Type 1 and Type 2 diabetes. The importance of understanding the mechanisms and signaling pathways regulating beta cell death is key in our ability to prolong beta cell survival in the future. One potential way to protect beta cells would be to use growth factors that can enhance their survival against different damaging insults. In this review, we describe the current knowledge on the effects of several beta cell growth factors that have been shown to increase beta cell survival in vitro and/or in vivo against varied cell death inducers. Understanding the mechanisms that mediate the pro-survival effects of these factors will enhance the potential to use these factors, or develop drugs that target their downstream pathways, as therapeutic agents for improved beta cell survival ex vivo or in vivo in the future.
\end{abstract}

Keywords: Diabetes, pancreatic beta cell, beta cell death, growth factors.

\section{INTRODUCTION}

Diabetes is one of the most prevalent and fastest growing diseases not only in the western world but surprisingly also in under-developed countries [1]. This epidemic is creating a phenomenal toll, both on the economics and on the health of nations worldwide [2]. Therefore, finding ways to combat, treat and cure this disease has become a priority in the health-care field. One of several approaches taken towards this goal is to better understand the etiology and cause of the disease, so that innovative cures can be found.

It is now well accepted that diabetes occurs due to a deficiency in the endogenous functional pancreatic beta cell mass, resulting in inadequate insulin supply and consequently, hyperglycemia. The two major forms of diabetes, Type 1, which results from an autoimmune attack on the beta cells, and Type 2, which encompasses components of insulin resistance as well as insufficient insulin production, both converge on the beta cell as the focal point of their phenotype [3-7]. The loss of functional beta cells in diabetes can result from an imbalance in proper beta cell differentiation, function, proliferation or death. Therefore, understanding the mediators, the cellular and molecular pathways, as well as factors that modulate these processes is extremely important in the ultimate treatment of the disease.

Pancreatic beta cell death is a key player in the pathogenesis of Type 1 diabetes, which is characterized by early stages of insulitis, islet infiltration by inflammatory cells, followed by a specific and progressive destruction of the beta cell. Both the extrinsic (cell-surface death receptors) as well as the intrinsic (mitochondrial) apoptotic pathways

\footnotetext{
*Address correspondence to this author at the Division of Endocrinology, University of Pittsburgh, 200 Lothrop St. - BST-E1157, Pittsburgh, PA 15261, USA; Tel: 412-648-3246; Fax: 412-648-3290;

E-mail: vasavada@pitt.edu
}

are involved in this process [6-11]. There is increasing evidence that beta cell death also plays a role in the etiology of Type 2 diabetes. Reduced beta cell mass as well as increased apoptosis in pancreatic sections from patients with Type 2 diabetes relative to normal non-diabetic subjects suggests that beta cell death may be directly involved in the reduction in functional pancreatic beta cell mass in these patients [3,4,11-14]. Furthermore, several animal models of Type 2 diabetes, such as the ob/ob and $\mathrm{db} / \mathrm{db}$ mice on a C57BL/KS background, transgenic rodents overexpressing the human islet amyloid polypeptide (hIAPP), the Zucker diabetic fatty rats, or Psammomys obesus, all show increased beta cell death with a resultant reduction in functional beta cell mass [15-20]. Thus, it is now well accepted that pancreatic beta cell death is a major regulator of the decreased beta cell mass observed in both Type 1 and Type 2 diabetes. Therefore, an understanding of the mediators and mechanisms of beta cell death, and more importantly, finding ways to enhance beta cell survival is critical in the treatment of this disease.

Numerous insults lead to beta cell death in the pathogenesis of diabetes. Immune-mediated inflammation and cytokines are vital mediators of beta cell destruction in Type 1 diabetes. Whereas in Type 2 diabetes, excessive nutrients leading to glucolipotoxicity (GLT), as well as toxicity due to accumulation of islet amyloid polypeptide (IAPP) oligomers are the major cause of beta cell loss [37,19-26]. There is accumulating evidence that the boundaries distinguishing the mediators of beta cell loss in Type 1 and Type 2 diabetes are becoming increasingly blurred. For example, recent evidence suggests that inflammation and cytokines are also involved in the loss of beta cells in Type 2 diabetes, and glucotoxicity in Type 1 diabetes $[27,28]$. The lack of nutrients and hypoxia are two other key effectors of beta cell death, besides glucotoxicity, that likely play a significant role in the massive loss of beta cells that occurs in the initial stages of islet transplantation [29], a procedure 
used for the treatment of severe cases of Type 1 diabetes [30]. Finally, glucocorticoids such as dexamethasone (DEX) $[31,32]$, and chemical beta cell toxins such as alloxan and streptozotocin (STZ) [32-35], also induce beta cell destruction, and the latter have been widely used to induce diabetes in animal models.

Depending on the nature and extent of the insult, it can induce necrotic, caspase-independent or caspase-dependent mitochondrial apoptotic, or cell-death receptor-mediated extrinsic apoptotic beta cell death pathways [36-39]. Beta cell death inducers mediate their action through common as well as distinct signaling pathways and molecular mechanisms. For example, synthesis of nitric oxide (NO), accumulation of reactive oxygen species (ROS), intracellular calcium, and activation of the endoplasmic reticulum (ER) stress pathway are common mediators downstream of a number of beta cell death effectors. The pro-apoptotic effects of cytokines are mediated through the activation of all three mitogen activated protein kinase (MAPK) pathways, with the c-Jun N-terminal kinase (JNK) pathway being the most important mediator of this process. The JNK pathway is also activated by the excessive production of ROS in beta cells as a consequence of prolonged exposure to hyperglycemia. The role of nuclear factor kappa $\mathrm{B}(\mathrm{NF \kappa B})$ activation, on the other hand, is somewhat more controversial in cytokineinduced beta cell death. There is in vitro evidence indicating a pro-apoptotic role for NFKB downstream of cytokines interleukin 1- $\beta$ (IL-1 $\beta)$ and interferon- $\gamma$ (IFN- $\gamma$ ), however, other studies suggest that $\mathrm{NF \kappa B}$ activation is protective against other cytokines such as IFN- $\gamma$ and tumor necrosis factor- $\alpha$ (TNF- $\alpha)$. There are numerous excellent reviews on the causes and mechanisms of beta cell death that the reader is referred to, as it is beyond the scope of this review [3$7,19-28,40]$.

There are numerous studies describing ways to inhibit beta cell death under different pathophysiological insults. These include use of growth factors, hormones, modulation of specific intracellular signaling pathways, and regulation of molecules involved in the apoptotic pathways. The current review specifically describes the role of growth factors and hormones in the regulation of beta cell survival, focusing on glucagon-like peptide-1 (GLP-1), parathyroid hormonerelated protein (PTHrP), lactogens, hepatocyte growth factor (HGF), insulin, and insulin-like growth factors (IGFs). In particular, we will emphasize what is known about the effects of these factors on beta cell survival in the context of (i) in vitro experiments; (ii) in vivo setting of transgenic overexpression or acute administration; (iii) in vivo setting of conditional gene deletion of the growth factor or its corresponding receptor; (iv) their action against varied cell death inducers; (v) and the signaling and molecular mechanisms involved (see Table $\mathbf{1}$ for summary).

\section{GLUCAGON-LIKE PEPTIDE-1 (GLP-1)}

\section{Introduction}

GLP-1 is a 30 -amino acid peptide hormone produced by differential processing of proglucagon in the intestinal epithelial endocrine L-cells in response to meal intake. The biologically active forms of GLP-1 consist of amino acids 737 or 7-36-amide. GLP-1 is rapidly metabolized and inactivated by the enzyme dipeptidyl peptidase IV with a resultant half life of less than two minutes in the circulation. The GLP-1 receptor is a class 2, G protein-coupled receptor which is widely distributed in pancreatic islets, brain, heart, kidney, and the gastrointestinal tract. The receptor typically couples via a stimulatory $\mathrm{G}$ protein to adenylate cyclase resulting in the formation of cAMP, and activates many other signaling pathways including MAPK, phosphoinositol 3-kinase (PI3K), Akt and atypical protein kinase C-zeta $(\operatorname{aPKC} \zeta)$. The main reported actions of GLP-1 are to: stimulate insulin secretion and increase insulin gene expression, inhibit glucagon secretion, inhibit gastrointestinal motility and secretion, regulate appetite and food intake, promote insulin sensitivity, and increase beta cell mass through enhanced proliferation and neogenesis [41-44].

\section{In Vitro Effects}

Another important function of GLP-1, especially relevant to this review, is its pro-survival effect on the pancreatic beta cell. GLP-1 protects beta cells against varied cell death inducers, demonstrated in vitro, in rodent insulinoma cell lines, in primary rodent and primary human beta cells. Human islets cultured for five days in the presence of GLP-1 maintained a better morphology and showed reduced beta cell death measured by condensed beta cell nuclei and active caspase-3 levels compared to control islets [45]. Studies from different groups have shown that GLP-1 can protect beta cells against cell death inducers relevant to Type 1 and Type 2 diabetes. Both GLP-1 and liraglutide, a long-acting analogue of GLP-1, protect neonatal rat islets from cytokine and free fatty acids (FFA) mediated cell death in a dosedependent manner. The maximal anti-apoptotic effects of GLP-1 occurred at 10 to $100 \mathrm{nM}$, a concentration of GLP-1 that is physiologically relevant, as $10 \mathrm{nM}$ corresponds to the plasma concentration of the incretin following a highcarbohydrate meal. Liraglutide was more potent in its prosurvival effects with maximal effects at 100 to $1000 \mathrm{nM}$. Pre-incubation with an excess of a GLP-1 antagonist exendin(9-39) completely blocked the protective effect of liraglutide against both cytokine and FFA-induced cell death demonstrating that its antiapoptotic effects are mediated via the GLP-1 receptor [46]. A separate study showed that 10 $\mathrm{nM}$ of GLP-1 also protects human islets as well as the rat insulinoma cell line INS832/13 against lipotoxicity, glucotoxicity and GLT [47]. Several groups have established the protective effect of GLP-1 against cytokine-mediated cell death in adult rodent and human islets [48-51]. The study from Kieffer's group took a different interesting approach. They induced GLP-1 production directly in the alpha cells of mouse islets through adenoviral (Ad) transduction of the cDNA for the processing enzyme prohormone convertase (PC) 1/3. This enzyme, which is normally absent in islet cells, is required for the processing of the proglucagon precursor to produce GLP-1. Bioactive GLP-1 released from Ad-PC 1/3 transduced islets increased in a dose-dependent manner, resulting in enhanced islet cell survival in response to IL-1 $\beta$ treatment [50]. GLP-1 and the GLP-1 receptor agonist, exendin-4, also protect beta cells against other cell death mediators including hydrogen peroxide $\left(\mathrm{H}_{2} \mathrm{O}_{2}\right)$, a potent generator of ROS, thapsigargin, an ER-stress inducer, a cocktail of immunosuppressive drugs (ISD) used to prevent rejection in islet transplantation and the glucocorticoid DEX. 
The protective effect of GLP-1 against $\mathrm{H}_{2} \mathrm{O}_{2}$ was observed in the mouse insulinoma cell line, MIN6, only when the cells were pre-treated with the peptide [52]. Also, GLP-1transfected MIN6 cells were protected against the toxicity induced by ISD [53]. Exendin-4 improved cell survival in INS-1 cells, and in rat and human islets, following induction of ER stress [54,55], and in mouse islets and INS-1 cells against DEX [31].

Of the various signaling pathways, PI3K/Akt and cAMP induction mediate the cytoprotective effects of GLP-1 in beta cells. Use of inhibitors demonstrated that GLP-1-induced activation of PI3K, but not MAPK, was required to inhibit the pro-apoptotic events in MIN6 cells exposed to $\mathrm{H}_{2} \mathrm{O}_{2}$ [52], as well in neonatal rat islets exposed to cytokines or FFA [46]. Similarly, overexpression of a dominant-negative protein kinase B mutant suppressed the anti-apoptotic action of GLP-1 against GLT in INS832/13 cells [47], substantiating the importance of the PI3K/Akt pathway in the pro-survival effect of GLP-1. The importance of the cAMP pathway in mediating the anti-apoptotic effect of GLP-1 was demonstrated using pharmacological inhibitors of this pathway in MIN6 cells against $\mathrm{H}_{2} \mathrm{O}_{2}$-induced cell death [52], in INS-1 cells against DEX-mediated cell death [31], as well as in primary rat beta cells against ER-stress induced beta cell death [54]. Exendin-4 significantly potentiated the induction of ER-stress response gene, activating transcription factor (ATF)-4, and accelerated recovery from ER stress-mediated translational repression in INS-1 cells in a PKA-dependent manner [54]. Exendin-4 also protected insulinoma cells and rat islets from cytokineinduced cell death by inhibiting the activation of the JNK pathway elicited by IL-1 $\beta$. The inhibition of JNK by exendin-4 was found to be PKA- but not PI3K-dependent [51]. A potential candidate signaling pathway that has not yet been explored in mediating the pro-survival effects of GLP-1 in beta cells is the atypical PKC $\zeta$ pathway, which although activated by GLP-1 in beta cells [56] and known to be a pro-survival signal in many cell types [57], has yet to be examined for its pro-survival effects in beta cells.

A very recent study showed that the anti-apoptotic actions of one growth factor, GLP-1, are mediated indirectly through regulating the signaling of another growth factor, IGF-II/IGF-I receptor. The study performed comparative transcriptomic analysis of islets from control and gastric inhibitory peptide (GIP) and GLP-1 double knockout mice and found that IGF-I receptor expression was markedly reduced in the mutant islets, which are more sensitive to cytokine-induced cell death. They demonstrated, both in MIN6 cells and in primary beta cells, that GLP-1 robustly stimulated IGF-I receptor expression and Akt phosphorylation. Furthermore, GLP-1-induced protection against apoptosis was shown to be mediated through an IGFII/IGF-I receptor autocrine loop, where GLP-1-induced IGFI receptor was activated by glucose-mediated IGF-II secretion and subsequent Akt phosphorylation [58].

Inhibition of beta cell apoptosis by GLP-1 against varied cell death inducers is associated with down-regulation of pro-apoptotic proteins including active caspase-3, caspase-12 poly-ADP-ribose polymerase cleavage, and thioredoxin interacting protein, and up-regulation of pro-survival factors including Bcl-2, Bcl-xL, islet-brain-1, JunB, inhibitor of apoptosis protein-2, and $\mathrm{BiP}$, the major chaperone protein of the ER [31,45-55,58]. The regulation of some of these genes by GLP-1 was found both at the mRNA and protein level. Buteau et al. found that GLP-1 enhanced NFKB DNA binding activity to the promoters of two anti-apoptotic genes, inhibitor of apoptosis protein-2 and Bcl-2, thus stimulating their expression. Inhibition of $\mathrm{NF} \kappa \mathrm{B}$ abolished the protective effect of GLP-1 against GLT in insulinoma cells [47]. On the other hand, Kang et al. found that exendin-4 inhibited IL-1 $\beta$ induced inducible nitric oxide synthase (iNOS) expression in insulinoma cells at the post-translational level and not at the transcriptional or post-transcriptional levels [59]. The role of the forkhead transcription factors of the $\mathrm{O}$ subclass (FoxO) in mediating the protective effect of GLP-1 was apparent when a constitutively nuclear FoxO1 prevented the antiapoptotic actions of GLP-1 against oxidative stress in insulinoma cells. GLP-1 inhibited FoxO1 binding to the promoter of the transcription factor pancreatic and duodenal homeobox gene-1 (Pdx1), thus promoting Pdx1 transcription. GLP-1 inhibited FoxO1 through phosphorylation-dependent nuclear exclusion, which was dependent on EGF receptor and PI3K activation, in INS832/13 cells [60].

\section{In Vivo Effects}

The pro-survival role of GLP-1 has also been well demonstrated in vivo in different animal models of diabetes. Endogenous GLP-1 receptor signaling directly modifies the susceptibility to apoptotic injury. GLP-1R-/- mice exhibited increased beta cell death relative to wild type controls, $48 \mathrm{hrs}$ after multiple low dose STZ (MLDS) treatment, a surrogate model of Type 1 diabetes. Conversely, normal C57B16 male mice pre-treated with exendin-4 for 3 days prior to MLDS administration were significantly protected from apoptosis resulting from this treatment [48]. Similarly, continuous infusion of recombinant GLP-1 at $1.5 \mathrm{pmol} / \mathrm{kg} / \mathrm{min}$ for $4-8$ weeks in another model of Type 1 diabetes, the NOD female mouse, led to a delay or suppression of the onset of diabetes, with a concomitant reduction in beta cell apoptosis [61]. Exendin-4 was also protective in animal models of Type 2 diabetes. Six week old female $\mathrm{db} / \mathrm{db}$ mice on a BKS background showed reduced beta cell death and prevention of hyperglycemia when injected daily intraperitoneally with $1 \mathrm{nmol} / \mathrm{kg}$ of exendin-4 for two weeks [62]. Similarly male Zucker diabetic fatty rats showed reduced cell death and caspase-staining in the beta cells of their pancreas when harvested at day 7 after a continuous infusion of recombinant GLP-1 at $30 \mathrm{pmol} / \mathrm{kg} / \mathrm{min}$ for two days [63]. Exendin-4 also reduced beta cell apoptosis in pancreatectomized (Px) rats treated with or without STZ, partly by attenuating the expression of ER-stress response genes such as $X$-boxbinding protein-1 (XBP-1), ATF-4, ATF6, and C/EBPhomologous protein (CHOP) [64]. The role of $\mathrm{Pdx} 1$ in mediating the pro-survival effect of exendin-4 in vivo was demonstrated using beta cell-specific Pdx1-/- mice. Treatment with exendin-4 for 3 days inhibited endogenous beta cell death in wild-type mice, but did not inhibit the increased beta cell apoptosis in beta cell-specific Pdx1-/mice [65]. Surprisingly, in the setting of syngeneic islet transplants under the kidney capsule of STZ-induced diabetic mice, exendin-4 treatment did not improve beta cell survival in these grafts at 1,3 , or 10 days post-transplant. 
Possible explanations for this surprising finding are that either the precise regimen used in these experiments was not ideal, or that pre-treatment with GLP-1 agonists may be required to mediate its protective effect [66]. Pre-treatment prior to the delivery of an insult has been employed in most models demonstrating GLP-1 receptor agonist-mediated $\beta$ cell cytoprotection in vitro or in vivo $[48,52,65]$.

There is convincing evidence to demonstrate that GLP-1 is a pro-survival factor in rodent beta cells under stressinduced conditions relating to both Type 1 and Type 2 diabetes in vitro and in vivo. PI3K/Akt and cAMP signaling pathways are the major mediators of the protective effect of GLP-1 in rodent beta cells. A number of specific molecular regulators of apoptosis including the Bcl family of proteins and ER-stress response genes are involved in this process. More focus on the human beta cell is required to better understand the specificity, mechanism and in vivo prosurvival effect of GLP-1 in human islets.

\section{PARATHYROID HORMONE-RELATED PROTEIN (PTHrP)}

\section{Introduction}

PTHrP was initially discovered as a tumor peptide that causes humoral hypercalcemia of malignancy, but subsequently was found to be expressed in almost all tissues of the body. PTHrP undergoes post-translational processing to give rise to several mature forms of the peptide, including the amino-terminal(1-36), mid-region(38-94), carboxylterminal(107-139) peptides, and a segment unique to primates, PTHrP(140-173). PTHrP is targeted to the secretory pathway by the signal peptide at its aminoterminus, and can also be targeted to the nucleus through its nuclear localization signal at amino acids 87-106. PTHrP functions as a potent smooth muscle relaxant, plays a role in transepithelial calcium transport, regulates proliferation, survival, differentiation and development in several tissues, and regulates epithelial-mesenchymal transition. The majority of the differentiation and developmental roles of PTHrP have been attributed to amino-terminal PTHrP(1-36), which interacts with a seven transmembrane G-protein coupled receptor, PTH/PTHrP receptor-1 (PTH1R), also found in all tissues where PTHrP is made, consistent with the known autocrine/paracrine functions of PTHrP [67-69].

\section{In Vitro Effects}

$\mathrm{PTHrP}$ is expressed in the pancreas during development [70,71], in the adult islet in all four endocrine cell types [72], and in insulinomas [72-74]. PTH1R is also expressed on the pancreatic beta cell $[75,76]$. In rodent beta cells, $\operatorname{PTHrP}(1-$ 36) stimulates the PKA/cAMP pathway resulting in increased expression of MAP kinase-specific phosphatase-1 (MKP-1) which causes dephosphorylation and inactivation of the JNK pathway [74,77]. PTHrP also activates the $\mathrm{Ca} / \mathrm{PKC}$, novel and atypical PKC pathways in rodent pancreatic beta cells $[78,79]$. PTHrP enhances beta cell proliferation and function $[74,77,79,80]$, and relevant to this review, is a survival factor for the rodent beta cell. Islet cell cultures from transgenic mice over-expressing PTHrP in their beta cells (RIP-PTHrP) are less prone to beta cell death induced by STZ or glucose and serum-deprivation, measured by TUNEL or propidium iodide co-staining with insulin, compared to normal littermates [81]. To determine which specific PTHrP peptide is responsible for the protective effect, normal mouse islet cell cultures deprived of glucose and serum were treated with either the amino(1-36), midregion(38-94), or the carboxyl(107-139) terminal PTHrP peptides. Only the amino-terminal(1-36) peptide significantly inhibited beta cell death, suggesting the importance of the PTHrP/PTH1R interaction for its prosurvival effects. There is a significant and specific increase in the level of anti-apoptotic Bcl2 mRNA in RIP-PTHrP transgenic islets; however, this increase did not clearly translate to the protein level [81]. The signaling and molecular pathways through which PTHrP mediates its antiapoptotic effects have yet to be delineated.

\section{In Vivo Effects}

PTHrP also has pro-survival effects on the rodent beta cell in vivo. Adult RIP-PTHrP transgenic mice were resistant to the diabetogenic and cytotoxic effects of STZ [81-83]. Uptake of STZ by the beta cell which occurs through the Glut2 transporter is likely to be similar in transgenic and normal islets, as the level of Glut2 was unchanged. To confirm that the resistance to STZ is not simply a result of the two-fold increase in beta cell area observed in adult transgenic mice, one-week old neonatal transgenic mice, which do not have increased islet mass, were treated with a single high dose of STZ for $24 \mathrm{hrs}$. Neonatal RIP-PTHrP mice showed decreased beta cell death and lower blood glucose levels compared to age-matched littermates, demonstrating an anti-apoptotic effect of PTHrP in rodent islets in vivo [81]. To examine whether PTHrP overexpression affected the increased wave of apoptosis reported in neonatal pancreas, pancreata from $11,13,15$ and 17 day old normal and RIP-PTHrP transgenic mice were analyzed for beta cell death by insulin and TUNEL costaining. Surprisingly, in these studies there was no increase in beta cell turnover in normal mice at any of these ages, nor was there a difference in the transgenic mice [Vasavada et al, unpublished results]. Thus, further studies are needed to determine whether PTHrP protects beta cells against other pathophysiologically relevant cell death inducers, and more importantly, whether it is a pro-survival factor for human beta cells.

\section{LACTOGENS}

\section{Introduction}

Prolactin (PRL), placental lactogen (PL) and growth hormone $(\mathrm{GH})$ are three of the major peptides that make up the family of lactogenic hormones. The major site of synthesis of PRL and GH is the lactotroph and the somatotroph cell of the anterior pituitary respectively, whereas PL is synthesized in the giant trophoblast cell of the placenta during pregnancy. These proteins consist of $\sim 200$ amino acids including a signal peptide, range in molecular weight from 22 to $25 \mathrm{Kd}$, and undergo post-translational modifications including glycosylation, phosphorylation and proteolytic cleavage. All three peptides signal through receptors $(\mathrm{R})$ which belong to the class 1 cytokine receptor superfamily. PRL and PL signal through a common PRL-R, whereas GH signals through a distinct GH-R. Both receptors are expressed in several different cell types including the beta cell, and can activate numerous downstream signaling 
pathways. GH is involved in the regulation of postnatal growth and metabolism, with its actions often mediated by IGF-I. PRL has a much broader spectrum of activities than $\mathrm{GH}$, and these are classified as reproduction, metabolism, osmoregulation, immunoregulation, and behavior. PL regulates maternal carbohydrate and lipid metabolism [8487].

\section{In Vitro Effects}

There is ample evidence demonstrating that lactogens can enhance beta cell function as well as proliferation [87-90]. Surprisingly, despite numerous studies indicating a prosurvival role of these peptides in other cell types [91-93], the effect on beta cell survival was not examined till recently. The first evidence suggesting a protective role of lactogens in beta cells is the study by Sorenson and colleagues, demonstrating decreased cell death in DEX-treated rat islets cultured in the presence of PRL [94]. More recently, our group has shown that $200 \mathrm{ng} / \mathrm{ml}$ of ovine PRL protects rat insulinoma cells INS-1 from STZ- and DEX-induced cell death, measured by cell viability assays and induction of cleaved caspase-3 [32]. Furthermore, primary mouse beta cells either overexpressing mouse placental lactogen 1 (mPL1) or treated exogenously with PRL are also protected from STZ- and DEX-induced cell death in vitro as measured by TUNEL and insulin co-staining (Fig. 1A, B) [32]. More recently, human islets cultured with PRL for 48 hrs showed a relative increase in islet beta cell content and viable beta cell mass compared to control non-treated islets [95].

To examine the signaling pathways responsible for the pro-survival effect of PRL, three different approaches, pharmacological inhibitors, siRNAs specific to Janusactivated kinase-2 (Jak-2), and a dominant negative (DN) mutant of signal transducer and activator of transcription-5 (Stat5), were used either in INS-1 cells or primary mouse beta cells. Neither the activation of PI3K/Akt nor the extracellular regulated kinase 1/2 (ERK 1/2) pathways were accountable for the pro-survival effects of PRL against DEX-induced beta cell death. Rather, the Jak-2/Stat5 pathway was shown to mediate the anti-apoptotic effects of PRL in INS-1 cells and primary mouse beta cells (Fig. 1C) [32]. One of several transcriptional targets downstream of Stat5 is the anti-apoptotic molecule Bcl-xL. PRL significantly increased the expression of Bcl-xL protein in INS- 1 cells by $6 \mathrm{hr}$, reaching a peak induction at $18 \mathrm{hr}$ and maintaining the increase for up to $24 \mathrm{hrs}$ (Fig. 1D, E). Similarly, primary mouse islets overexpressing mPL-1 in their beta cells also showed an increase in Bcl-xL expression, compared to normal islets. Using Bcl-xL-specific siRNA, lactogen-induced up-regulation of Bcl-xL was shown to be required to mediate its protective effect in INS-1 cells against DEX-induced cell death (Fig. 1F, G). However, Bcl-xL-specific siRNA significantly reduced, but did not completely abolish, the protective effect of PRL suggesting that there could be additional molecular pathways through which PRL mediates its pro-survival effect in beta cells (Fig. 1G) [32]. In this regard, a study examining the transcriptional modulation of genes by PRL in rat islets by DNA microarray analysis identified pro-apoptotic genes such as clusterin, NFKBIA, and TNFRSF1A as being downregulated by PRL [96].
The role of $\mathrm{GH}$ in beta cell survival has barely been examined. Bovine GH inhibits cytokine-induced nitric oxide production by reducing iNOS gene induction in INS-1 cells. To elucidate the underlying mechanism, activation of transcription factors implicated in the induction of iNOS was examined, and only Statl tyrosine phosphorylation and DNA binding was inhibited by $\mathrm{GH}$, but not that of NFkB. GH was found to induce suppressor of cytokine signaling (SOCS)-1 and -3 , both of which are able to inhibit cytokine-activation of Stat1, suggesting that they are likely to mediate the inhibitory action of GH [97]. A more recent study showed that human (h) GH reduces the apoptotic effects of cytokines in INS-1 cells. hGH only slightly reduced cytokine-induced iNOS gene expression, and unlike the other study, hGH further increased cytokine-induced nitric oxide production and had no effect on either Stat1 or NFKB binding in INS-1 cells, despite enhanced SOCS-3 expression. Finally, the antiapoptotic effect of hGH was mediated through Stat5 activation resulting in an increase in the Bcl-xL/Bax ratio in INS-1 cells [98]. One caveat of the latter study [98] is that human GH was used on rodent beta cells, and it has been previously demonstrated that hGH can interact and signal through the rodent PRL-R [87,99]. Therefore, it is unclear whether GH acting through its own receptor indeed has antiapoptotic effects on the rodent beta cell. Although the former study [97] used bovine GH which signals through the GH-R, they did not directly demonstrate an anti-apoptotic effect of $\mathrm{GH}$ against cytokine-induced cell death.

\section{In Vivo Effects}

Whether lactogens have a protective effect on beta cells in vivo, was examined in transgenic mice, RIP-mPL1, overexpressing mPL-1 in their beta cells. Adult transgenic mice were completely protected from the diabetogenic effects of a single high dose of STZ, compared to normal littermates, up to 4 weeks after STZ injection [76, 90]. Furthermore, the RIP-mPL-1 mice were also protected from the cytotoxic effects of STZ in vivo, as demonstrated by reduced beta cell death $14 \mathrm{hrs}$ after an STZ injection, as well as a 10 -fold increase in the remnant beta cell mass 4 weeks after STZ treatment, relative to normal littermates [76]. One other study found that daily injections of PRL for 13 weeks in pre-diabetic NOD mice resulted in a lower incidence of Type 1 diabetes compared to the saline treated control group, although the results were not significant. Also, this study did not examine the contributions of increased proliferation versus decreased cell death by PRL in these mice [100]. Future studies will examine the anti-apoptotic role of lactogens against pathophysiologically relevant cell death inducers in vitro and in vivo, as well as in human islets.

\section{HEPATOCYTE GROWTH FACTOR (HGF)}

\section{Introduction}

HGF is a mesenchyme-derived protein originally identified as a circulating factor that promotes hepatic regeneration after liver injury. Since then, many studies have demonstrated that HGF has mitogenic, motogenic, antiapoptotic, angiogenic, and morphogenic activities in a wide variety of cell types. To exert its functions, HGF needs to be activated through proteolysis by serine proteases, and forms a disulfide-linked heterodimer composed of a $69-\mathrm{kDa}$ alpha- 
A.

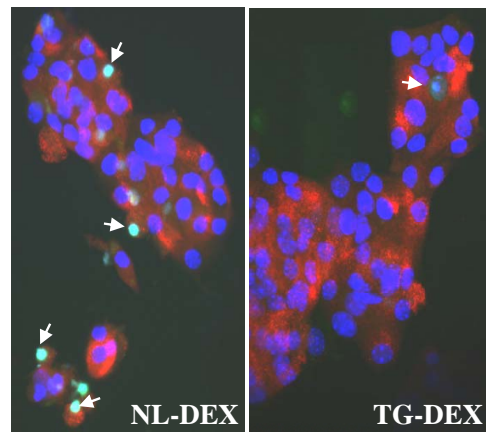

D.
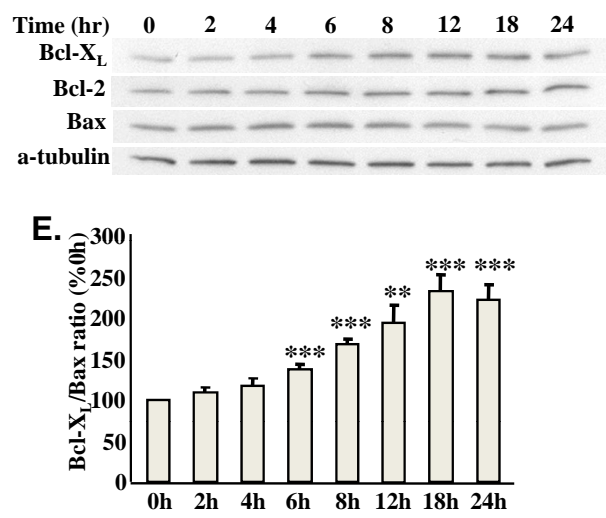

B.

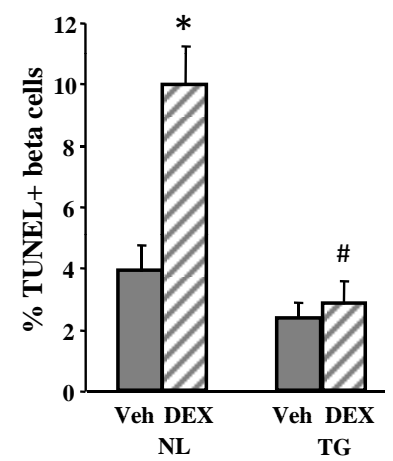

F.
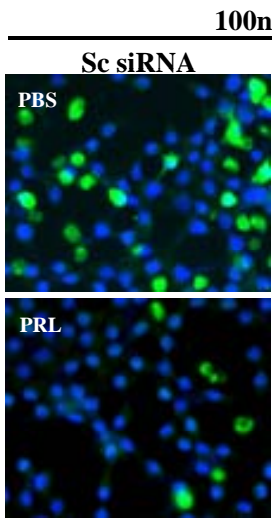

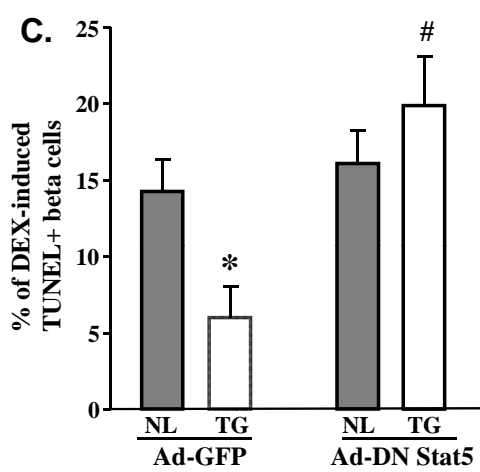

G.

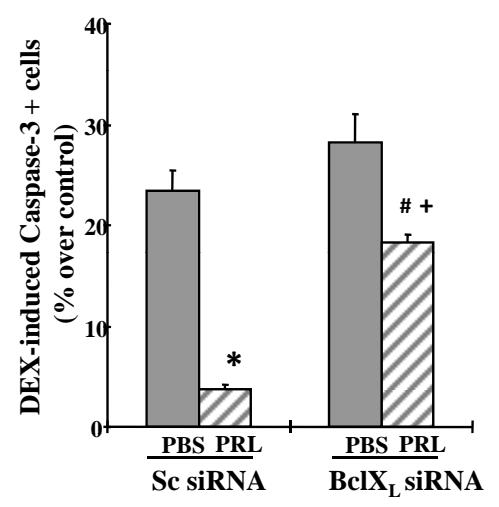

Fig. (1). Lactogens protect mouse primary beta cells and INS-1 cells against DEX-induced cell death in vitro. A) Primary islet cell cultures from normal (NL) and RIP-mPL1 transgenic (TG) mice stained for insulin (red), TUNEL (green), and Hoechst 33258 (blue) after 48 hrs of $500 \mathrm{nM}$ DEX-treatment. Arrows indicate TUNEL-positive beta cells. B) Quantitation of the percentage of TUNEL-positive beta cells in NL and TG islet cell cultures treated with vehicle (Veh, gray bars) or DEX (stippled bars) shows a significant 2.5 -fold increase in DEXinduced beta cell death in NL cells which is completely and significantly inhibited in TG islet cells $(* p<0.001$ versus veh, \# p $<0.001$ versus DEX.) C) Transduction with Ad-DN-Stat5 completely blocks the protective effect of lactogens on DEX-induced beta cell death in primary mouse islet cells. (* $\mathrm{p}<0.05$ versus NL Ad-GFP, \# $\mathrm{p}<0.05$ versus TG Ad-GFP). D) Western blot analysis of Bcl-xL, Bcl2, Bax, and tubulin expression in INS-1 cells treated with PRL for different times. E) Densitometric analysis of the ratio of Bcl-xL/Bax depicted as percentage of untreated cells. (* $\mathrm{p}<0.05)$. F) INS-1 cells transfected with scrambled $(\mathrm{Sc})$ or Bcl-xL siRNA, treated with DEX \pm PRL, were stained for cleaved caspase-3 (green) and Hoechst 33258 (blue). G) Quantitation of the percentage of caspase-3-positive cells shows Bcl-xL siRNA significantly diminished the protective effect of PRL against DEX-induced INS-1 cell death. $(* \mathrm{p}<0.0001$, Sc siRNA-transfected cells PBS versus PRL; + $<<0.0005$, PRL-treated cells Sc versus Bcl-xL siRNA-transfected; \# $<<0.05$, Bcl-xL siRNA-transfected cells PBS versus PRL). ["This research was originally published in the Journal of Biological Chemistry. Fujinaka Y, Takane K, Yamashita H, Vasavada RC. Lactogens promote beta cell survival through JAK2/STAT5 activation and BclXL upregulation. J Biol Chem 2007; 282: 30707-17. (C) the American Society for Biochemistry and Molecular Biology. '].

chain and a 34-kDa beta-chain. HGF binds with high affinity to, and induces the dimerization of, a membrane-spanning tyrosine kinase receptor encoded by the proto-oncogene, cmet. The receptor and ligand have widespread distribution, including in the pancreatic islet [101-103].

\section{In Vitro Effects}

Several studies have demonstrated that HGF is a mitogen and an insulinotropic agent for fetal and adult islet cells in vitro and in vivo [104-109]. The role of HGF on pancreatic beta cell survival has been examined more recently. HGF enhances survival of porcine neonatal pancreatic cell clusters (NPCC) transfected with Epstein-Barr virus (EBV)-based HGF plasmid [110], and reduces beta cell death in islets of non-human primates (NHP) transfected with Ad-mouse HGF in vitro [111]. HGF also confers protection against STZ in vitro. Cell viability of INS-1 cells 24 hrs after STZ treatment was significantly improved with the addition of $25 \mathrm{ng} / \mathrm{ml}$ of HGF [112]. HGF activated the PI3K/Akt signaling pathway in both INS-1 cells and mouse islets. An inhibitor of this pathway abrogated the pro-survival effect of HGF against STZ in INS-1 cells, indicating the importance of the PI3K pathway in mediating the anti-apoptotic effect of HGF [112]. Another study found that HGF protects the rat insulinoma cell line, RINm5F, against FFA-mediated apoptosis. Treatment with $50 \mathrm{ng} / \mathrm{ml}$ of HGF every $8 \mathrm{hrs}$ significantly inhibited cell death in RINm5F cells exposed to a mixture of FFAs (oleate:palmitate 2:1) for $72 \mathrm{hrs}$. HGF exerted its prosurvival effect by counteracting, the increased intracellular oxidative stress and decreased expression of the antiapoptotic molecule Bcl-2, induced by prolonged FFAs 
exposure. As in the previous study this pro-survival effect is mediated through activation of PI3K [113].

Contrary to the pro-survival effects of HGF demonstrated thus far, a rather surprising finding was uncovered in a very recent study [114]. Garcia-Ocaña's group showed that HGF can be detrimental for beta cell survival in an environment with excessive fatty acid supply. They found that normal mouse islet cell cultures treated with HGF peptide, or transgenic mouse beta cells overexpressing HGF (RIP-HGF) display enhanced sensitivity to apoptosis mediated by incremental concentrations of palmitate in vitro. The proapoptotic effect of HGF peptide to palmitate-induced beta cell death was dose-dependent, peaking at $10 \mathrm{ng} / \mathrm{ml}$ of HGF. HGF-overexpressing islets show significantly decreased AMP-activated protein kinase (AMPK)- $\alpha$ and acetyl-CoA carboxylase (ACC) phosphorylation, diminished fatty acid oxidation (FAO), increased serine palmitoyltransferase (SPT) expression and enhanced ceramide formation compared with normal islets. Importantly, they found that human islets overexpressing HGF are also more susceptible to palmitate-induced beta cell apoptosis. Inhibition of de novo ceramide synthesis abrogated beta cell apoptosis induced by HGF and palmitate treatment in both mouse and human islet cells [114]. Thus, the authors surmise that the normal action of HGF, which is to induce glucose metabolism and glycolysis, is detrimental in the presence of palmitate, as it could lead to elevated malonyl-CoA which would inhibit carnitine palmitoyltransferase-I activity thereby reducing fatty acid oxidation, increasing ceramide synthesis, and ultimately resulting in enhanced beta cell death. As discussed in their study, the potential explanations for the opposite pro- and anti-apoptotic effects of HGF against FFAs observed in their study [114] versus that from Anastasi's group [113] are: i) the use of primary beta cells versus insulinoma cells which could exhibit very different glucose and lipid metabolic profiles, and ii) the composition of FFAs used, palmitate versus a mixture of oleate and palmitate, where oleate has been shown previously to have pro-survival effects on the beta cell.

\section{In Vivo Effects}

The protective effect of HGF on the beta cell has also been demonstrated in vivo. RIP-HGF transgenic mice that overexpress HGF in their beta cells are resistant to the diabetogenic effects of STZ for up to a month, as well as to its cytotoxic effects in vivo [108,112]. Administration of naked DNA containing HGF prior to the induction of diabetes by STZ, also protected beta cells from cell death, and conferred resistance to the diabetogenic effects up to 7 days [115]. Interestingly, intravenous injection of an adenovirus containing HGF cDNA into mice previously rendered diabetic by MLDS also resulted in amelioration of hyperglycemia and increased insulin-positive cells/islet after two weeks; however, the effect of HGF on beta cell death was not directly measured in this study [116]. Another in vivo situation where HGF was protective of beta cells was in the setting of islet transplants. The first few hours and days after islet transplant are characterized by substantial islet dysfunction and death [29]. RIP-HGF transgenic and AdHGF-transduced mouse islets transplanted under the kidney capsule of STZ-induced diabetic severe combined immunodeficient (SCID) mice substantially improved their blood glucose [109,112]. The number of condensed, pyknotic beta cell nuclei was significantly reduced and the insulin content was significantly increased $24 \mathrm{hrs}$ after the transplant in Ad-HGF grafts compared with control Ad-beta galactosidase (LacZ) grafts [112]. Similar results were obtained when islets from another species, NHP, transduced with Ad-mouse HGF were transplanted under the kidney capsule of diabetic SCID mice [111]. Using Ad-HGF in a different islet transplant model that more closely resembles human islet transplantation protocols, i.e., an intraportal allogeneic rat islet transplant using the same immunosuppressants employed by the Edmonton group, also showed markedly improved islet transplant outcomes. The number and size of islets remaining in the liver 25 days after transplant were significantly higher in the Ad-HGFtransduced versus Adv-LacZ-transduced islets, suggesting improved survival, although beta cell death was not directly measured in this study [117]. As with the in vitro studies, the only condition in which HGF seems to be potentially detrimental to the beta cell in vivo is in the state of obesity. The improved glucose homeostasis and increased beta cell mass and proliferation observed in RIP-HGF transgenic mice relative to normal littermates fed with standard chow $[108,109,114]$ is completely lost following 15 weeks of highfat feeding [114]. Furthermore, there is an increase, although not significant, in beta cell apoptosis in vivo in RIP-HGF mice compared to normal littermates put on a high-fat diet [114]. Future studies will determine whether HGF is protective against cytokine-induced cell death and whether endogenous HGF/c-met signaling is critical for beta cell survival in different situations of stress.

\section{INSULIN AND INSULIN-LIKE GROWTH FACTORS (IGFs)}

\section{Introduction}

Insulin, IGF-I and IGF-II belong to the IGF family and share at least a 50\% homology in their amino acid sequence. All three peptides are expressed in distinct cell types of the pancreas at different stages of development. Insulin first detected very early in pancreatic development (E8.5), continues to be expressed and secreted from the beta cell through adulthood with a short half-life in minutes, circulating at picomolar concentrations. IGFs, on the other hand, are synthesized and secreted mainly from the liver, but are also made locally in almost every tissue, including the pancreas, with a half-life in hours determined by interaction with the IGF binding proteins (IGFBPs) and the acid-labile subunit, and circulate at nanomolar concentrations. Insulin and IGF-I mediate their action through two distinct tyrosine kinase receptors, the insulin receptor (IR) made in beta cells, and the IGF-I receptor (IGF-IR) present on alpha, beta and delta cells, of the pancreas respectively. At higher concentrations the peptides can also cross-react with the complementary receptor. IGF-II can activate both the IGF-IR and the IR (A-subtype) and also binds to a third receptor, IGFII- mannose-6-phosphate receptor, which likely regulates the degradation of IGF-II [118-121].

\section{In Vitro Effects}

As with the other growth factors, insulin and IGFs also potentiate the function and growth of the pancreatic beta cell [122-125]. Several studies have now shown that insulin and 
IGFs are important pro-survival factors as well for the beta cell. In vitro culture experiments found rodent insulinoma cell lines as well as primary rodent and human beta cells are protected from glucose and/or serum-deprived cell death in the presence of exogenous insulin or IGFs [126-131]. Interestingly, the pro-survival effect of insulin on mouse and human beta cells was manifested only at low, more physiological concentrations, in the picomolar to low nanomolar range, but not at higher concentrations [130]. Similarly, IGF-II exhibited a dose-dependent effect at 50$500 \mathrm{ng} / \mathrm{ml}$ concentrations to increase the viability and decrease the apoptotic index of rat islets cultured in vitro [127]. Importantly, glucose was shown to mediate its prosurvival effects on the beta cell through the secretion of insulin. This was demonstrated in MIN-6 cells using insulin antibody or through deletion of the IR in mouse beta cells $[129,132]$. Insulin and IGFs also protect insulinoma cells against other cell death inducing agents including STZ [133], DEX [134], and ER-stress [135]. Several studies demonstrate the anti-apoptotic effects of insulin, IGF-I and IGF-II on cytokine-mediated beta cell death. Pretreatment of insulinoma cells, adult or 22-day old rat islets, and islets from pre-diabetic NOD female mice with insulin, IGF-I or IGF-II was effective in protecting against cytokine-mediated apoptotic cell death [136-142]. In this regard, Hill's group found that IGF-I was present in vivo in islets from prediabetic NOD mice that did not demonstrate insulitis, but not in islets with extensive immune infiltration, as seen by immunohistochemistry [139]. Similarly, IGF-II was expressed and present in fetal and neonatal islet cells, but declined rapidly 2 weeks after birth, with little IGF-I associated with fetal or postnatal islets [138]. They further demonstrated that the endogenous IGF-II was protective against cytokine-mediated cell death in vitro, since islets from 5-day old rats were not susceptible to cytokine-induced cell death unless treated with an IGF-II antibody [138]. Finally, human islets were also protected against IL-1 $\beta$ induced, Fas-mediated apoptosis after adenoviral gene transfer of human IGF-I [140].

The anti-apoptotic effect of IGF-1/insulin against serum deprivation-induced apoptosis in RINm5F cells is prevented with inhibitors of NO generation, PI3K and Akt, and the dominant negative form of the tyrosine kinase c-Src [131]. However, in mouse islets physiological levels of insulin did not increase Akt phosphorylation, and the protective effect of insulin was only partially altered in serum-deprived islets lacking $80 \%$ of normal Akt activity, suggesting the presence of additional insulin-regulated anti-apoptotic pathways [130]. Similarly, inhibition of DEX-induced apoptosis in INS-1 cells by IGF-I was mediated through ERK phosphorylation and not through PI3K activation, as demonstrated with specific inhibitors of these pathways [134]. A general mechanism of IGF-I action in insulinoma cells, rodent islets and human islets subjected to cytokines is a reduction in cytokine-induced NOS expression and NO production. This effect appears to be mainly dependent on the activation of PI3K and an inhibition of NFKB activation [133,136,140-142]. IGF-I elevated expression of Bcl-2 and Bcl-xL proteins, and diminished caspase- 9 activity, in cytokine-treated insulinoma cells and islets from NOD mice [142]. Finally, Pdx1 seems to play an important part in the pro-survival effect of insulin. Mouse islets treated with insulin showed nuclear localization of $\mathrm{Pdx} 1$, and more importantly, the pro-survival effects of insulin were largely absent in islets $50 \%$ deficient in Pdx1. Also, proteomic analysis of insulin-treated human islets revealed significant changes in a Pdx1-binding partner and regulator of beta cell survival, Bridge-1 [130].

\section{In Vivo Effects}

The pro-survival roles of insulin and IGFs have also been substantiated in vivo in the beta cell. These factors have been proven to protect against induction of Type 1 diabetes in the MLDS and NOD mouse models using both transgenic and acute peptide administration approaches. Several transgenic mouse models overexpressing IGF-I, either using the metallothionein promoter [143] or the rat insulin promoter in two different genetic backgrounds (C57BL/6-SJL and CD-1) of mice [125] displayed resistance to MLDS-induced diabetes and insulitis, and specifically reduced beta cell death in STZ-treated mice. Similarly, double transgenic mice that simultaneously overexpress IFN- $\gamma$ and IGF-I in their beta cells had reduced 2-microglobulin expression, decreased Fas expression, and reduced islet infiltration, with a parallel decrease in STZ-induced apoptotic cell death relative to single IFN- $\gamma$ overexpressing transgenic mice [144]. Acute administration of IGF-I, IGF-I derived peptides, or IGFI/IGFBP-3 complex reduced the severity of insulitis and delayed the onset of diabetes in NOD mice $[142,145,146]$. The IGF-I/IGFBP-3 complex was more stable and afforded more efficient protection from insulitis and beta cell destruction than IGF-I [142]. IGF-II was also found to have pro-survival effects on the beta cell in vivo. Persistent circulating levels of IGF-II, in a keratin promoter driven IGF-II transgenic mouse model, suppressed the normal wave of beta cell apoptosis observed in neonatal pancreas [147]. Also, transplantation of IGF-II pre-treated rat islets in diabetic mice was much more effective in making mice normoglycemic compared to untreated islets, however, beta cell death was not directly measured in this study [127].

To assess the physiological role of locally produced IGFI, pancreatic specific IGF-I gene deficient (PID) mice were generated by crossing Pdx1-Cre and IGF-I/loxP mice. Surprisingly, when challenged with MLDS the PID mice were more resistant to STZ-induced hyperglycemia and beta cell death compared to normal littermates, suggesting that endogenous locally produced IGF-I is detrimental for beta cell survival under conditions of MLDS [148]. Similarly, the role of endogenous insulin on beta cell survival was examined in mice with targeted disruption of the two nonallelic insulin genes. As these mice develop severe diabetes and die within $48 \mathrm{hrs}$ of birth, the endocrine pancreas in late gestation was examined, and found to have reduced beta cell apoptosis, again suggesting that endogenous insulin is detrimental to beta cell survival [149]. Whether the detrimental phenotypes in these two knock out mouse models is due to compensatory changes in other growth factors, or cross-reactivity of the receptors with other members of this family, is not known. In contrast, mouse models lacking functional receptors for either insulin or IGF1 only in the beta cell, did not exhibit any major phenotype. However, when both receptors were simultaneously deleted from the beta cell to create the double knock out mouse (bDKO), they developed diabetes 3 weeks after birth. 
Interestingly, bDKO mice manifested increased apoptosis in their beta cells even at 2-weeks of age when these mice were normoglycemic, indicating that the endogenous peptides have a pro-survival function in the beta cell [150].

\section{OTHER FACTORS}

The factors described above are by no means a comprehensive list of growth factors and hormones that affect pancreatic beta cell survival. There are previous reports and some more recent studies describing antiapoptotic actions of several other growth factors on the pancreatic beta cell. These include, and again may not be limited to, nerve growth factor (NGF), fibroblast growth factor (FGF), epidermal growth factor (EGF), transforming growth factor (TGF), stromal cell derived factor, ghrelin, thyroid hormone, leptin and estradiol. However, studies on the effects of these factors on beta cell survival are limited, and therefore, have not been included in the current review.

\section{CONCLUSION}

The field describing the effects of various factors on beta cell survival and their mode of action is rapidly expanding. It is clear from a review of this literature (see Table $\mathbf{1}$ and
Fig. (2) for summary) that the state of knowledge in this regard varies greatly between the different factors. Some obvious patterns that emerge are: i) the same factor can have differential effects on beta cell survival depending on the insult; ii) there is often interplay between factors to mediate their action, for example, GLP-1 mediates its pro-survival function through activation of the IGF or the EGF signaling pathways; iii) activation of PI3K/Akt and cAMP pathways most commonly mediate the pro-survival effects, with activation of ERK $1 / 2$ and inhibition of JNK pathways also playing a role; and, iv) inhibition of apoptosis is mediated most commonly through regulation of the bcl family of molecules, ER-stress response, and NO production for cytokine-mediated cell death.

The importance of knowing which factor can have prosurvival effects against specific cell death inducers, and understanding the pathways and mechanisms of their action, is obvious. It provides the potential to use these factors as therapeutic agents for improved beta cell survival ex vivo or in vivo. Specifically, one can envision using a combination of factors for maximal benefits on beta cell survival under conditions of varying susceptibility. It is of interest that all

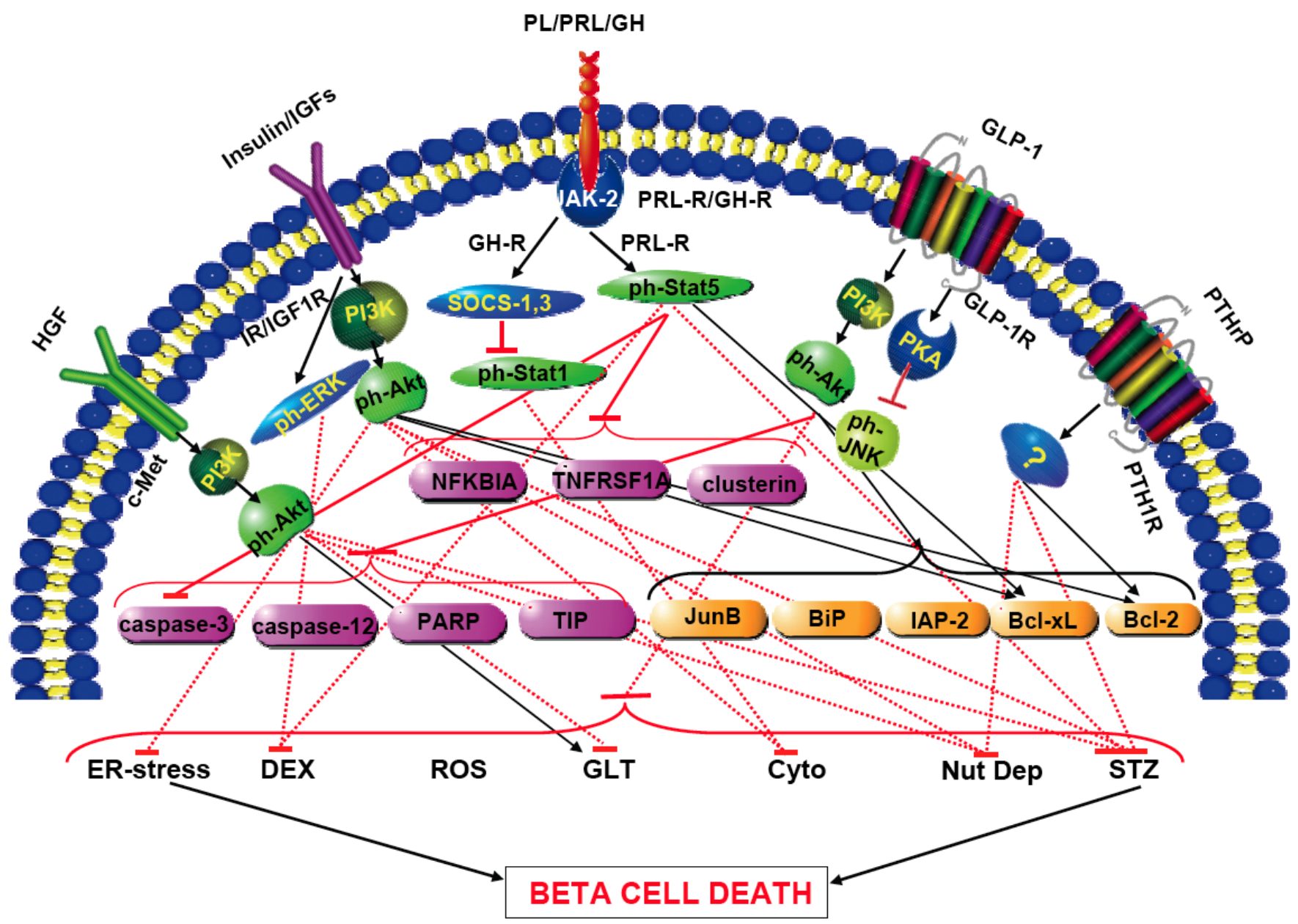

Fig. (2). Schematic representation summarizing the signaling pathways and molecular mediators through which growth factors modulate beta cell death against specific cell death effectors. Activation (black arrows) and inhibition (red lines) of targets downstream of the growth factors, and their effect on beta cell death against specific cell death stimuli. See text for abbreviations; TIP (thioredoxin interacting protein), Nut Dep (Nutrient Deprivation). 
Table 1. Summary of Effects Induced by the Different Growth Factors on Beta Cell Death Described in this Review

\begin{tabular}{|c|c|c|c|c|c|}
\hline Growth Factor & Cell Death Inducers & Approach & Effect & Intracellular Effectors & Ref. \\
\hline \multicolumn{6}{|l|}{ GLP-1 } \\
\hline & \multicolumn{5}{|l|}{ In vitro: } \\
\hline & Culture & Human islets/GLP-1 & $\downarrow \beta$-cell death & & {$[45]$} \\
\hline & \multirow[t]{2}{*}{ Gluco/Lipotoxicity } & Neonatal rat islets/GLP-1 \& liraglutide & $\downarrow \beta$-cell death & $\uparrow \mathrm{PI} 3 \mathrm{~K}$ & {$[46]$} \\
\hline & & INS832/13 cells; human islets/GLP-1 & $\downarrow \beta$-cell death & $\uparrow \mathrm{PI} 3 \mathrm{~K} ; \uparrow \mathrm{NF} \kappa \mathrm{B}$ binding; $\uparrow \mathrm{Bcl}-2, \mathrm{IAP}-2$ & {$[47]$} \\
\hline & \multirow[t]{8}{*}{ Cytokines } & Neonatal rat islets/GLP-1 \& liraglutide & $\downarrow \beta$-cell death & $\uparrow \mathrm{PI} 3 \mathrm{~K}$ & {$[46]$} \\
\hline & & Rat islets/exendin-4 & $\downarrow \beta$-cell death & & {$[48]$} \\
\hline & & INS-1E cells; Rat islets/exendin-4 & $\downarrow \beta$-cell death & $\uparrow$ phAkt; $\downarrow$ caspase-3, iNOS, $\downarrow$ ROS & {$[49]$} \\
\hline & & Mouse islets/Ad-PC1/3 & $\downarrow \beta$-cell death & & {$[50]$} \\
\hline & & INS-1E cells; Rat islets/exendin-4 & $\downarrow \beta$-cell death & $\begin{array}{l}\uparrow \mathrm{PKA} ; \downarrow J \mathrm{JK} ; \uparrow \text { islet-brain } 1 \\
\text { transcription }\end{array}$ & {$[51]$} \\
\hline & & MIN6 cells; mouse islets/GLP-1 & $\downarrow \beta$-cell death & $\uparrow p h A k t ; \uparrow I G F-I R$, IGF-II & {$[58]$} \\
\hline & & $\begin{array}{l}\mathrm{GIPR}^{-/} / \mathrm{GLP}-1 \mathrm{R}^{-/} \text {double knockout mouse } \\
\text { islets }\end{array}$ & $\uparrow \beta$-cell death & $\downarrow$ IGF-IR & {$[58]$} \\
\hline & & RINm5F cells/exendin- 4 & & $\uparrow \mathrm{cAMP} ; \downarrow$ iNOS post-translationally & {$[59]$} \\
\hline & \multirow[t]{2}{*}{ ER-stress } & Rat islets; INS-1 cells/exendin-4 & $\downarrow \beta$-cell death & $\uparrow \mathrm{PKA} ; \uparrow \mathrm{ATF}-4$ translation & {$[54]$} \\
\hline & & Rat islets; INS-1E cells/exendin-4 & $\downarrow \beta$-cell death & $\uparrow \mathrm{BiP}$, JunB, XIAP; $\downarrow$ caspase-12 & {$[55]$} \\
\hline & \multirow[t]{2}{*}{ ROS } & MIN6 cells/GLP-1 & $\downarrow \beta$-cell death & $\begin{array}{l}\uparrow \mathrm{PI} 3 \mathrm{~K}, \mathrm{cAMP} ; \uparrow \mathrm{Bcl}-2, \mathrm{Bcl}-\mathrm{xL} ; \\
\downarrow \mathrm{PARP} \text { cleavage }\end{array}$ & {$[52]$} \\
\hline & & INS832/13 cells/GLP-1 & $\downarrow \beta$-cell death & $\uparrow \mathrm{PI} 3 \mathrm{~K}, \mathrm{EGFR} ; \downarrow$ FoxO1 & {$[60]$} \\
\hline & DEX & INS-1 cells; Mouse islets/exendin-4 & $\downarrow \beta$-cell death & $\uparrow \mathrm{PKA}$ & {$[31]$} \\
\hline & $\begin{array}{l}\text { Immunosuppressive } \\
\text { drugs }\end{array}$ & GLP-1-transfected MIN6 cells & $\downarrow \beta$-cell death & $\uparrow$ Bcl-2; $\downarrow$ PARP, Smac/ Diablo & {$[53]$} \\
\hline & \multicolumn{5}{|l|}{ In vivo: } \\
\hline & MLDS/48 hrs & GLP-1R $\mathrm{R}^{-/}$mice & $\uparrow \beta$-cell death & & {$[48]$} \\
\hline & MLDS & C57B16 male mice exendin- 4 & $\downarrow \beta$-cell death & & {$[48]$} \\
\hline & NOD female mice & GLP-1/4-8 weeks & $\begin{array}{l}\downarrow \beta \text {-cell death; } \\
\text { delayed onset of } \\
\text { diabetes }\end{array}$ & & {$[61]$} \\
\hline & $\begin{array}{l}\mathrm{db} / \mathrm{db} \text { BKS female } \\
\text { mice }\end{array}$ & Exendin-4/2 weeks & $\begin{array}{l}\downarrow \beta \text {-cell death; no } \\
\text { hyperglycemia }\end{array}$ & & {$[62]$} \\
\hline & $\begin{array}{l}\text { Male Zucker diabetic } \\
\text { fatty rats }\end{array}$ & GLP-1/2 days & $\downarrow \beta$-cell death & $\downarrow$ caspase-3 & {$[63]$} \\
\hline & Px rats $\pm \mathrm{STZ}$ & Exendin-4/4 weeks & $\downarrow \beta$-cell death & $\downarrow X B P-1, A T F 4, A T F 6, C H O P$ & {$[64]$} \\
\hline & $\mathrm{Pdx}-1^{-/}$mice & Exendin- $4 / 3$ days & $\uparrow \beta$-cell death & & {$[65]$} \\
\hline & $\begin{array}{l}\text { Syngeneic mouse islet } \\
\text { transplants }\end{array}$ & Exendin-4/1,3,10 days & $\leftrightarrow \beta$-cell death & & {$[66]$} \\
\hline \multicolumn{6}{|l|}{ PTHrP } \\
\hline & \multicolumn{5}{|l|}{ In vitro: } \\
\hline & $\begin{array}{l}\text { Glucose/Serum } \\
\text { deprivation }\end{array}$ & RIP-PTHrP Tg mouse islet cell culture & $\downarrow \beta$-cell death & $\uparrow B c l-2$ & {$[81]$} \\
\hline & & Mouse islet cells/PTHrP peptides & $\downarrow \beta$-cell death & Mediated by amino-terminus PTHrP & [81] \\
\hline & STZ & RIP-PTHrP Tg mouse islet cell culture & $\downarrow \beta$-cell death & & [81] \\
\hline & \multicolumn{5}{|l|}{ In vivo: } \\
\hline & STZ & Adult RIP-PTHrP Tg mice & $\begin{array}{l}\downarrow \text { hyperglycemia; } \\
\downarrow \beta \text {-cell death }\end{array}$ & & $\begin{array}{l}{[82,83]} \\
{[81,83]}\end{array}$ \\
\hline
\end{tabular}


(Table 1) contd.....

\begin{tabular}{|c|c|c|c|c|c|}
\hline Growth Factor & Cell Death Inducers & Approach & Effect & Intracellular Effectors & Ref. \\
\hline & & Neonatal RIP-PTHrP Tg mice & $\begin{array}{l}\downarrow \text { hyyperglycemia; } \\
\downarrow \beta \text {-cell death }\end{array}$ & & {$[81]$} \\
\hline & Neonatal apoptosis & $\begin{array}{l}\text { Neonatal RIP-PTHrP Tg mice:11,13,15, } 17 \\
\text { days }\end{array}$ & $\leftrightarrow \beta$-cell death & & $\begin{array}{l}\text { [Vasavada } \\
\text { et al. } \\
\text { unpublished } \\
\text { results] }\end{array}$ \\
\hline \multicolumn{6}{|l|}{ Lactogens } \\
\hline & \multicolumn{5}{|l|}{ In vitro: } \\
\hline & \multirow[t]{2}{*}{ DEX } & $\begin{array}{l}\text { Rat islets/PRL } \\
\text { INS-1 cells/oPRL }\end{array}$ & $\begin{array}{l}\downarrow \beta \text {-cell death } \\
\downarrow \beta \text {-cell death }\end{array}$ & $\downarrow$ caspase-3; $\uparrow \mathrm{Jak} 2 / \mathrm{Stat} 5 ; \uparrow \mathrm{Bcl}-\mathrm{xL}$ & $\begin{array}{l}{[94]} \\
{[32]}\end{array}$ \\
\hline & & Mouse islets/oPRL RIP-mPL1 Tg islets & $\downarrow \beta$-cell death & $\uparrow \mathrm{Jak} 2 / \mathrm{Stat} 5 ; \uparrow \mathrm{Bcl}-\mathrm{xL}$ & [32] \\
\hline & \multirow[t]{2}{*}{ STZ } & INS-1 cells/oPRL & $\downarrow \beta$-cell death & $\downarrow$ caspase-3 & [32] \\
\hline & & RIP-mPL1 Tg islets & $\downarrow \beta$-cell death & & [32] \\
\hline & Culture & Human islets/PRL & $\uparrow$ viable $\beta$-cells & & [95] \\
\hline & \multirow[t]{2}{*}{ Cytokines } & INS-1 cells/bovine GH & & $\downarrow$ iNOS; $\downarrow$ phStat $1 ; \uparrow$ SOCS- 1,3 & [97] \\
\hline & & INS-1 cells/human GH & $\downarrow \beta$-cell death & $\downarrow$ iNOS; $\uparrow$ phStat5; $\uparrow$ SOCS-3; $\uparrow$ Bcl-xL & [98] \\
\hline & \multicolumn{5}{|l|}{ In vivo: } \\
\hline & STZ & Adult RIP-mPL1 Tg mice & $\begin{array}{l}\downarrow \text { hyperglycemia; } \\
\downarrow \beta \text {-cell death }\end{array}$ & & $\begin{array}{l}{[76,90]} \\
{[76]}\end{array}$ \\
\hline & NOD mice & PRL/13 weeks & $\begin{array}{l}\text { delayed diabetes } \\
\text { onset }\end{array}$ & & {$[100]$} \\
\hline \multicolumn{6}{|l|}{ HGF } \\
\hline & \multicolumn{5}{|l|}{ In vitro: } \\
\hline & \multirow[t]{2}{*}{ Culture } & Porcine NPCC/EBV-HGF & $\uparrow \beta$-cell survival & & [110] \\
\hline & & NHP islets/Ad-mouse HGF & $\downarrow \beta$-cell death & & [111] \\
\hline & STZ & INS-1 cells/HGF & $\downarrow \beta$-cell death & $\uparrow \mathrm{PI} 3 \mathrm{~K}$ & [112] \\
\hline & \multicolumn{5}{|l|}{ Lipotoxicity } \\
\hline & Palmitate + Oleate & RINm5F cells/HGF & $\downarrow \beta$-cell death & $\uparrow \mathrm{PI} 3 \mathrm{~K} ; \uparrow \mathrm{Bcl}-2$ & [113] \\
\hline & Palmitate & Mouse islets/HGF & $\uparrow \beta$-cell death & & [114] \\
\hline & Palmitate & RIP-HGF Tg islets & $\uparrow \beta$-cell death & $\begin{array}{l}\text { \phAMPK, phACC, FAO, } \uparrow \text { SPT, } \\
\text { Ceramide }\end{array}$ & [114] \\
\hline & Palmitate & Human islets/Ad-HGF & $\uparrow \beta$-cell death & $\uparrow$ Ceramide & [114] \\
\hline & \multicolumn{5}{|l|}{ In vivo: } \\
\hline & \multirow[t]{2}{*}{ STZ } & Adult RIP-HGF Tg mice & $\begin{array}{l}\downarrow \text { hyperglycemia; } \\
\downarrow \beta \text {-cell death }\end{array}$ & & $\begin{array}{l}{[108]} \\
{[112]}\end{array}$ \\
\hline & & Male CD1 mice/naked HGF DNA & $\begin{array}{l}\downarrow \text { hyperglycemia; } \\
\downarrow \beta \text {-cell death }\end{array}$ & & [115] \\
\hline & MLDS & BalbC male mice/Ad-HGF & $\downarrow$ hyperglycemia & & [116] \\
\hline & \multirow[t]{3}{*}{ Islet transplants } & Diabetic SCIDs/RIP-HGF, & $\begin{array}{l}\downarrow \text { hyperglycemia; } \\
\downarrow \beta \text {-cell death }\end{array}$ & & $\begin{array}{l}{[109]} \\
{[112]}\end{array}$ \\
\hline & & Diabetic SCIDs/Ad-HGF NHP islets & $\begin{array}{l}\downarrow \text { hyperglycemia; } \\
\downarrow \beta \text {-cell death }\end{array}$ & & [111] \\
\hline & & Allogeneic rats/Ad-HGF rat islets intraportally & $\downarrow$ hyperglycemia & & [117] \\
\hline & High fat diet $/ 15$ weeks & Adult RIP-HGF Tg mice & $\uparrow \beta$-cell death & & [114] \\
\hline \multicolumn{6}{|l|}{ IGFs/Insulin } \\
\hline & \multicolumn{5}{|l|}{ In vitro: } \\
\hline & \multirow[t]{2}{*}{ Culture } & Hamster islets/IGF-II & $\downarrow \beta$-cell death & & [126] \\
\hline & & Rat islets/IGF-II & $\downarrow \beta$-cell death & & [127] \\
\hline
\end{tabular}


(Table 1) contd...

\begin{tabular}{|c|c|c|c|c|c|}
\hline Growth Factor & Cell Death Inducers & Approach & Effect & Intracellular Effectors & Ref. \\
\hline & & Rat islets/Insulin antibody & $\uparrow \beta$-cell death & & [128] \\
\hline & Glucose/Serum & Rat islets/Insulin & $\downarrow \beta$-cell death & & [128] \\
\hline & \multirow[t]{8}{*}{ Deprivation } & Mouse, human islets/Insulin & $\downarrow \beta$-cell death & $\uparrow \mathrm{Pdx}-1$ nuclear localization; $\uparrow$ Bridge-1 & [130] \\
\hline & & $\mathrm{Pdx}-1^{+/-}$islets & $\uparrow \beta$-cell death & & [130] \\
\hline & & RINm5F cells; rat, human Islets/Insulin; IGF-I & $\downarrow \beta$-cell death & $\begin{array}{l}\uparrow \mathrm{PI} 3 \mathrm{~K}, \mathrm{c}-\mathrm{src} ; \uparrow \mathrm{NOS} 3, \mathrm{NO} ; \uparrow \text { phIRS-1, } \\
\text { phIRS-2 }\end{array}$ & [131] \\
\hline & & $\beta$-cell specific IRKO cells & $\uparrow \beta$-cell death & $\downarrow$ phAkt; $\uparrow$ caspase 3 , phFoxo1 & [132] \\
\hline & & Mouse beta cells/Insulin; & $\downarrow \beta$-cell death & & [132] \\
\hline & & IR antibody & $\uparrow \beta$-cell death & & \\
\hline & & MIN6 cells/cisplatin/Insulin & $\downarrow \beta$-cell death & & [129] \\
\hline & & Rat islets/Insulin & $\downarrow \beta$-cell death & & [128] \\
\hline & STZ & RINm5F cells/Ad-IGF-I & $\downarrow \beta$-cell death & $\downarrow \mathrm{NO}$ & [133] \\
\hline & DEX & INS-1 cells/IGF-I & $\downarrow \beta$-cell death & $\uparrow p h E R K$ & [134] \\
\hline & \multirow[t]{2}{*}{ ER-stress } & MIN6 cells/IGF-I & $\downarrow \beta$-cell death & $\uparrow p h A k t ; \downarrow$ PARP cleavage & [135] \\
\hline & & MIN6 cells/IR siRNAs & $\uparrow \beta$-cell death & & [135] \\
\hline & \multirow[t]{8}{*}{ Cytokines } & Rat islets/IGF-I & $\downarrow \beta$-cell death & $\downarrow$ NOS & [136] \\
\hline & & Neonatal rat islets/IGF-I, insulin & $\downarrow \beta$-cell death & & [137] \\
\hline & & $\sim 22$ day rat islets/IGF-I, IGF-II & $\downarrow \beta$-cell death & & {$[138]$} \\
\hline & & $\sim 5$ day rat islets/IGF-II antibody & $\uparrow \beta$-cell death & & [138] \\
\hline & & $\begin{array}{l}\text { Pre-diabetic female NOD mice islets/IGF- } \\
\text { I,IGF-II }\end{array}$ & $\downarrow \beta$-cell death & & [139] \\
\hline & & Human islets/Ad-IGF-I & $\downarrow \beta$-cell death & $\downarrow \mathrm{NO}$ & [140] \\
\hline & & INS-1 cells/IGF-I & $\downarrow \beta$-cell death & $\uparrow \mathrm{PI} 3 \mathrm{~K} ; \downarrow$ IKK activity; $\downarrow$ NOS2 & [141] \\
\hline & & NIT-1 cells, NOD mouse islets/IGF-I & $\downarrow \beta$-cell death & $\begin{array}{l}\uparrow \mathrm{PI} 3 \mathrm{~K}, \text { phAkt; } \downarrow \text { caspase activity; } \uparrow \text { Bcl- } \\
\mathrm{xL}, \mathrm{Bcl}-2\end{array}$ & [142] \\
\hline & \multicolumn{5}{|l|}{ In vivo: } \\
\hline & \multirow[t]{3}{*}{ MLDS } & Metallothionein-I promoter IGF-I Tg mice & $\begin{array}{l}\downarrow \text { hyperglycemia } \\
\downarrow \beta \text {-cell death }\end{array}$ & & [143] \\
\hline & & $\begin{array}{l}\text { RIP-IGF-I Tg mice on CD1, C57BL/6-SJL } \\
\text { strains }\end{array}$ & $\begin{array}{l}\downarrow \text { hyperglycemia } \\
\downarrow \beta \text {-cell death }\end{array}$ & & [125] \\
\hline & & Pdx-Cre x IGF-I/loxP KO mice & $\downarrow \beta$-cell death & & {$[148]$} \\
\hline & \multirow{3}{*}{$\begin{array}{l}\text { RIP-IFN } \gamma \text { mice/STZ } \\
\text { NOD mice }\end{array}$} & RIP-IFN $\gamma /$ RIP-IGF-I double Tg mice & $\downarrow \beta$-cell death & $\downarrow 2$-microglobulin, Fas & [144] \\
\hline & & IGF-I peptides & $\downarrow$ hyperglycemia & & {$[145,146]$} \\
\hline & & IGF-I/IGFBP-3 complex & $\downarrow \beta$-cell death & $\downarrow$ caspase-3 & [142] \\
\hline & Neonatal apoptosis & Keratin promoter IGF-IITg mice & $\begin{array}{l}\downarrow \text { neonatal } \beta \text {-cell } \\
\text { death }\end{array}$ & & [147] \\
\hline & Islet transplants & $\begin{array}{l}\text { Diabetic SCIDs/Rat islets pre-treated with } \\
\text { IGF-II }\end{array}$ & $\downarrow$ hyperglycemia; & & [127] \\
\hline & $\begin{array}{l}\text { Ins } 1^{-1 /} / \text { Ins } 2^{-/-} \text {double } \\
\text { KO mice }\end{array}$ & e18.5, newborn & $\downarrow \beta$-cell death & & [149] \\
\hline & $\beta$-cell specific & 2 weeks & $\uparrow \beta$-cell death & & [150] \\
\hline & $\begin{array}{l}\mathrm{IR}^{-/} / \mathrm{IGF}_{\mathrm{I}} \mathrm{IR}^{-/} \text {double } \\
\mathrm{KO} \text { mice }\end{array}$ & & $\leftrightarrow$ glycemia & & \\
\hline
\end{tabular}

Note: Transgenic mouse (Tg); No changes (↔); Knockout (KO); refer to other abbreviations in the text.

the factors described above not only augment beta cell survival but are also known to potentiate beta cell growth and function, thereby enhancing their potential as future therapeutic agents for beta cell regeneration. As each of these peptides is secreted, and can exogenously manifest its action through receptors, it has the potential to be acutely 
administered for treatment. A drawback to this method would be the non-specific effects of these factors on other organs where receptors are present. However, several of these factors are already being administered as drugs or are in clinical trial, underscoring the feasibility of this approach. Finally, understanding the downstream mechanisms that mediate the pro-survival effects of these factors could identify common pathways that can be targeted in the future for development of drugs to improve beta cell survival.

\section{ACKNOWLEDGEMENTS}

This work was supported by grants to RCV from the National Institutes of Health (DK078060 and DK072264), and the Juvenile Diabetes Research Foundation (1-2008-46).

\section{REFERENCES}

[1] Wild S, Roglic J, Green A, et al. Global prevalence of diabetes. Estimates for the year 2000 and projections for 2030. Diabetes Care 2004; 27: 1047-53.

[2] American Diabetes Association. Costs of diabetes in the U.S. in 2007. Diabetes Care 2008; 31: 596-615.

[3] Meier JJ. Beta cell mass in diabetes: a realistic therapeutic target? Diabetologia 2008; 51: 703-13.

[4] Bonner-Weir S, O'Brien TD. Islets in type 2 diabetes: in honor of Dr. Robert C. Turner. Diabetes 2008; 57: 2899-904.

[5] Chang-Chen KJ, Mullur R, Bernal-Mizrachi E. Beta-cell failure as a complication of diabetes. Rev Endocr Metab Disord 2008; 9: 329-43.

[6] Donath MY, Størling J, Berchtold LA, et al. Cytokines and betacell biology: from concept to clinical translation. Endocr Rev 2008; 29: $334-50$.

[7] Donath MY, Halban PA. Decreased $\beta$-cell mass in diabetes: significance, mechanisms and therapeutic implications. Diabetologia 2004; 47: 581-9.

[8] Gepts W. Pathologic anatomy of the pancreas in juvenile diabetes mellitus. Diabetes 1965; 14: 619-63.

[9] Meier JJ, Bhushan A, Butler AE, et al. Sustained beta cell apoptosis in patients with long-standing type 1 diabetes: indirect evidence for islet regeneration? Diabetologia 2005; 48: 2221-8.

[10] Butler AE, Galasso R, Meier JJ, et al. Modestly increased beta cell apoptosis but no increased beta cell replication in recent-onset type 1 diabetic patients who died of diabetic ketoacidosis. Diabetologia 2007; 50: 2323-31.

[11] Kloppel G, Lohr M, Habich K, et al. Islet pathology and the pathogenesis of type 1 and type 2 diabetes mellitus revisited. Surv Synth Pathol Res 1985; 4: 110-25.

[12] Butler AE, Janson J, Bonner-Weir S, et al. $\beta$-cell deficit and increased $\beta$-cell apoptosis in humans with type 2 diabetes. Diabetes 2003; 52: 102-10.

[13] Sakuraba B, Mizukami H, Yagihashi N, et al. Reduced $\beta$-cell mass and expression of oxidative stress-related DNA damage in the islet of Japanese type II diabetes mellitus. Diabetologia 2002; 45: 85-96.

[14] Yoon KH, Ko SH, Cho JH, et al. Selective $\beta$-cell loss and $\alpha$-cell expansion in patients with type 2 diabetes mellitus in Korea. J Clin Endocrinol Metab 2003; 88: 2300-8.

[15] Shafrir E, Ziv E, Mosthaf L. Nutritionally induced insulin resistance and receptor defect leading to beta-cell failure in animal models. Ann N Y Acad Sci 1999; 892: 223-46.

[16] Leiter EH, Coleman DL, Hummel KP. The influence of genetic background on the expression of mutations at the diabetes locus in the mouse. III. Effect of H-2 haplotype and sex. Diabetes 1981; 30: 1029-34.

[17] Bar-On H, Ben-Sasson R, Ziv E, et al. Irreversibility of nutritionally induced NIDDM in Psammomys obesus is related to beta-cell apoptosis. Pancreas 1999; 18: 259-65.

[18] Pick A, Clark J, Kubstrup C, et al. Role of apoptosis in failure of $\beta$ cell mass compensation for insulin resistance and $\beta$-cell defects in the male Zucker diabetic fatty rat. Diabetes 1998; 47: 358-64.

[19] Huang CJ, Lin CY, Haataja L, et al. High expression rates of human islet amyloid polypeptide induce endoplasmic reticulum stress mediated beta-cell apoptosis, a characteristic of humans with type 2 but not type 1 diabetes. Diabetes 2007; 56: 2016-27.
[20] Huang CJ, Haataja L, Gurlo T, et al. Induction of endoplasmic reticulum stress-induced beta-cell apoptosis and accumulation of polyubiquitinated proteins by human islet amyloid polypeptide. Am J Physiol Endocrinol Metab. 2007; 293: E1656-62.

[21] Wajchenberg BL. Beta-cell failure in diabetes and preservation by clinical treatment. Endocr Rev 2007; 28: 187-218.

[22] Poitout V, Robertson RP. Glucolipotoxicity: fuel excess and betacell dysfunction. Endocr Rev 2008; 29: 351-66.

[23] Haataja L, Gurlo T, Huang CJ, et al. Islet amyloid in type 2 diabetes, and the toxic oligomer hypothesis. Endocr Rev 2008; 29: 303-16.

[24] Cnop M, Igoillo-Esteve M, Cunha DA, et al. An update on lipotoxic endoplasmic reticulum stress in pancreatic $\beta$-cells. Biochem Soc Trans 2008; 36: 909-15.

[25] Prentki M, Nolan CJ. Islet beta cell failure in type 2 diabetes. J Clin Invest 2006; 116: 1802-12.

[26] Scheuner D, Kaufman RJ. The unfolded protein response: a pathway that links insulin demand with beta-cell failure and diabetes. Endocr Rev 2008; 29: 317-33.

[27] Donath MY, Størling J, Maedler K, et al. Inflammatory mediators and islet beta-cell failure: a link between type 1 and type 2 diabetes. J Mol Med 2003; 81: 455-70.

[28] Ehses JA, Böni-Schnetzler M, Faulenbach M, et al. Macrophages, cytokines and beta-cell death in Type 2 diabetes. Biochem Soc Trans 2008; 36: 340-2

[29] Davalli AM, Scaglia L, Zangen DH, et al. Vulnerability of islets in the immediate post-transplantation period: Dynamic changes in structure and function. Diabetes 1996; 45: 1161-7.

[30] Nanji SA, Shapiro AM. Advances in pancreatic islet transplantation in humans. Diabetes Obes Metab. 2006; 8: 15-25.

[31] Ranta F, Avram D, Berchtold S, et al. Dexamethasone induces cell death in insulin-secreting cells, an effect reversed by exendin- 4 . Diabetes 2006; 55: 1380-90.

[32] Fujinaka Y, Takane K, Yamashita H, et al. Lactogens promote beta cell survival through JAK2/STAT5 activation and Bcl-XL upregulation. J Biol Chem 2007; 282: 30707-17.

[33] Like AA, Rossini AA. Streptozotocin-induced pancreatic insulitis: new model of diabetes mellitus. Science 1976; 193: 415-7.

[34] Masutani M, Suzuki H, Kamada N, et al. Poly(ADP-ribose) polymerase gene disruption conferred mice resistant to streptozotocin-induced diabetes. Proc Natl Acad Sci USA 1999; 96: 2301-4.

[35] Rerup CC. Drugs producing diabetes through damage of the insulin secreting cells. Pharmacol Rev 1970; 22: 485-518.

[36] Hengartner MO. The biochemistry of apoptosis. Nature 2000; 407: 770-6.

[37] Hong SJ, Dawson TM, Dawson VL. Nuclear and mitochondrial conversations in cell death: PARP-1 and AIF signaling. Trends Pharmacol Sci 2004; 25: 259-64.

[38] Thomas FT, Contreras JL, Bilbao G, et al. Anoikis, extracellular matrix, and apoptosis factors in isolated cell transplantation. Surgery 1999; 126: 299-304.

[39] Kay TW, Thomas HE, Harrison LC, et al. The beta cell in autoimmune diabetes: many mechanisms and pathways of loss. Trends Endocrinol Metab 2000; 11: 11-5.

[40] Kim S, Millet I, Kim HS, et al. NF-אB prevents $\beta$ cell death and autoimmune diabetes in NOD mice. Proc Natl Acad Sci USA 2007; 104: 1913-8.

[41] Salehi M, Aulinger BA, D'Alessio DA. Targeting $\beta$-cell Mass in type 2 diabetes: Promise and limitations of new drugs based on incretins. Endocr Rev 2008; 29: 367-79.

[42] Baggio LL, Drucker DJ. Biology of incretins: GLP-1 and GIP. Gastroenterology 2007; 132: 2131-57.

[43] De León DD, Crutchlow MF, Ham JY, et al. Role of glucagon-like peptide-1 in the pathogenesis and treatment of diabetes mellitus. Int J Biochem Cell Biol. 2006; 38: 845-59.

[44] Perfetti R, Hui H. The role of GLP-1 in the life and death of pancreatic beta cells. Horm Metab Res 2004; 36: 804-10.

[45] Farilla L, Bulotta A, Hirshberg B, et al. Glucagon-like peptide 1 inhibits cell apoptosis and improves glucose responsiveness of freshly isolated human islets. Endocrinology 2003; 144: 5149-58.

[46] Bregenholt S, Moldrup A, Blume N, et al. The long-acting glucagon-like peptide-1 analogue, liraglutide, inhibits $\beta$-cell apoptosis in vitro. Biochem Biophys Res Commun 2005; 330: 57784. 
[47] Buteau J, El-Assaad W, Rhodes CJ, et al. Glucagon-like peptide-1 prevents beta cell glucolipotoxicity. Diabetologia 2004; 47: 806-15.

[48] Li Y, Hansotia T, Yusta B, et al. Glucagon-like peptide-1 receptor signaling modulates beta cell apoptosis. J Biol Chem 2003; 278 : 471-8.

[49] Li L, El-Kholy W, Rhodes CJ, et al. Glucagon-like peptide-1 protects beta cells from cytokine-induced apoptosis and necrosis: role of protein kinase B. Diabetologia 2005; 48: 1339-49.

[50] Wideman RD, Yu IL, Webber TD, et al. Improving function and survival of pancreatic islets by endogenous production of glucagonlike peptide 1 (GLP-1). Proc Natl Acad Sci USA 2006; 103: 1346873.

[51] Ferdaoussi M, Abdelli S, Yang JY, et al. Exendin-4 protects betacells from interleukin-1 beta-induced apoptosis by interfering with the c-Jun NH2-terminal kinase pathway. Diabetes 2008; 57: 120515.

[52] Hui H, Nourparvar A, Zhao X, et al. Glucagon-like peptide-1 inhibits apoptosis of insulin-secreting cells via a cyclic 5-adenosine monophosphate-dependent protein kinase A- and a phosphatidylinositol 3-kinase-dependent pathway. Endocrinology 2003; 144: 1444-55.

[53] D'Amico E, Hui H, Khoury N, et al. Pancreatic beta-cells expressing GLP-1 are resistant to the toxic effects of immunosuppressive drugs. J Mol Endocrinol. 2005; 34: 377-90.

[54] Yusta B, Baggio LL, Estall JL, et al. GLP-1 receptor activation improves beta cell function and survival following induction of endoplasmic reticulum stress. Cell Metab 2006; 4: 391-406.

[55] Cunha DA, Ladrière L, Ortis F, et al. Glucagon-like peptide-1 agonists protect pancreatic beta-cells from lipotoxic endoplasmic reticulum stress through upregulation of BiP and JunB. Diabetes 2009; 58: 2851-62.

[56] Buteau J, Foisy S, Rhodes CJ, et al. Protein kinase C $\zeta$ activation mediates glucagon-like peptide-1-induced pancreatic $\beta$-cell proliferation. Diabetes 2001; 50: 2237-43.

[57] Wooten MW. Function for NF- $\kappa$ B in neuronal survival: Regulation by atypical protein kinase C. J Neurosci Res 1999; 58: 607-11.

[58] Cornu M, Yang JY, Jaccard E, et al. Glucagon-like peptide-1 protects beta-cells against apoptosis by increasing the activity of an IGF-2/IGF-1 receptor autocrine loop. Diabetes 2009; 58: 1816-25.

[59] Kang JH, Chang SY, Jang HJ, et al. Exendin-4 inhibits interleukin1beta-induced iNOS expression at the protein level, but not at the transcriptional and posttranscriptional levels, in RINm5F beta-cells. J Endocrinol 2009; 202: 65-75.

[60] Buteau J, Spatz ML, Accili D. Transcription factor FoxO1 mediates glucagon-like peptide-1 effects on pancreatic $\beta$-cell mass. Diabetes 2006; 55: 1190-6.

[61] Zhang J, Tokui Y, Yamagata K, et al. Continuous stimulation of human glucagon-like peptide-1 (7-36) amide in a mouse model (NOD) delays onset of autoimmune type 1 diabetes. Diabetologia 2007; 50: 1900-9.

[62] Wang Q, Brubaker PL. Glucagon-like peptide-1 treatment delays the onset of diabetes in 8-week-old db/db mice. Diabetologia 2002; 45: 1263-73.

[63] Farilla L, Hui H, Bertolotto C, et al. Glucagon-like peptide-1 promotes islet cell growth and inhibits apoptosis in Zucker diabetic rats. Endocrinology 2002; 143: 4397-408.

[64] Kwon DY, Kim YS, Ahn IS, et al. Exendin-4 potentiates insulinotropic action partly via increasing beta-cell proliferation and neogenesis and decreasing apoptosis in association with the attenuation of endoplasmic reticulum stress in islets of diabetic rats. J Pharmacol Sci. 2009; 111: 361-71.

[65] Li Y, Cao X, Li LX, et al. Beta-cell Pdx1 expression is essential for the glucoregulatory, proliferative, and cytoprotective actions of glucagon-like peptide-1. Diabetes 2005; 54: 482-91.

[66] Crutchlow MF, Yu M, Bae YS, et al. Exendin-4 does not promote Beta-cell proliferation or survival during the early post-islet transplant period in mice. Transplant Proc 2008; 40: 1650-7.

[67] Philbrick WM, Wysolmerski JJ, Galbraith S, et al. Defining the roles of parathyroid hormone-related protein in normal physiology. Physiol Rev 1996; 76: 127-73.

[68] Lanske B, Kronenberg HM. Parathyroid hormone-related peptide (PTHrP) and parathyroid hormone (PTH)/PTHrP receptor. Crit Rev Eukaryot Gene Exp 1998; 8: 297-320.

[69] Kronenberg HM, Lanske B, Kovacs CS, et al. Functional analysis of the PTH/PTHrP network of ligands and receptors. Recent Prog Horm Res 1998; 53: 283-303.
[70] Campos RV, Asa SL, Drucker DJ. Immunocytochemical localization of parathyroid hormone-like peptide in the rat fetus. Cancer Res 1991; 51: 6351-7.

[71] Moseley JM, Hayman JA, Danks JA, et al. Immunohistochemical detection of parathyroid hormone-related protein in human fetal epithelia. J Clin Endocrinol Metab 1991; 73: 478-84.

[72] Drucker DJ, Asa SL, Henderson J, et al. The parathyroid hormonelike peptide gene is expressed in the normal and neoplastic human endocrine pancreas. Mol Endocrinol 1989; 3: 1589-95.

[73] Sawada Y, Kameya T, Aizama T, et al. Proprotein-processing endoprotease furin and its substrate parathyroid hormone-related protein are coexpressed in insulinoma cells. Endocr Pathol 2000; 11:31-9.

[74] Sawada Y, Kameya T, Aizama T, et al. PTHrP increases pancreatic beta-cell-specific functions in well-differentiated cells. Mol Cell Endocrinol 2001; 182: 265-75

[75] Karperien M, van Dijk TB, Hoeijmakers $\mathrm{T}$, et al. Expression pattern of parathyroid hormone/parathyroid hormone related peptide receptor mRNA in mouse postimplantation embryos indicates involvement in multiple developmental processes. Mech Dev 1994; 47: 29-42.

[76] Fujinaka Y, Sipula D, Garcia-Ocaña A, et al. Characterization of mice doubly transgenic for parathyroid hormone-related protein and murine placental lactogen: A novel role for placental lactogen in pancreatic beta cell survival. Diabetes 2004; 53: 3120-30.

[77] Zhang B, Hosaka M, Sawada Y, et al. Parathyroid hormone-related protein induces insulin expression through activation of MAP kinase-specific phosphatase-1 that dephosphorylates c-Jun NH(2)terminal kinase in pancreatic beta-cells. Diabetes 2003; 52: 272030 .

[78] Gaich G, Orloff JJ, Atillasoy EJ, et al. Amino-terminal parathyroid hormone-related protein: specific binding and cytosolic calcium responses in rat insulinoma cells. Endocrinology 1993; 132: 14029.

[79] Villanueva-Penacarrillo ML, Cancelas J, de Miguel F, et al. Parathyroid hormone-related peptide stimulates DNA synthesis and insulin secretion in pancreatic islets. J Endocrinol 1999; 163: 4038.

[80] Vasavada RC, Wang L, Fujinaka Y, et al. Protein kinase C-zeta activation markedly enhances beta-cell proliferation: an essential role in growth factor mediated beta-cell mitogenesis. Diabetes 2007; 56: 2732-43.

[81] Cebrian A, Garcia-Ocaña A, Takane KK, et al. Overexpression of parathyroid hormone-related protein inhibits pancreatic beta cell death in vivo and in vitro. Diabetes 2002; 51: 3003-13.

[82] Porter SE, Sorenson RL, Dann P, et al. Progressive pancreatic islet hyperplasia in the islet-targeted, parathyroid hormone-related protein-overexpressing mouse. Endocrinology 1998; 139: 3743-51.

[83] Fujinaka Y, Sipula D, Garcia-Ocaña A, et al. Characterization of mice doubly transgenic for parathyroid hormone-related protein and murine placental lactogen: A novel role for placental lactogen in pancreatic beta cell survival. Diabetes 2004; 53: 3120-30.

[84] Goffin V, Shiverick KT, Kelly PA, et al. Sequence-function relationships within the expanding family of prolactin, growth hormone, placental lactogen, and related proteins in mammals. Endocr Rev 1996; 17: 385-410.

[85] Talamantes F. Structure and regulation of secretion of mouse placental lactogens. Prog Clin Biol Res 1990; 342: 81-5.

[86] Goffin V, Binart N, Clement-Lacroix P, et al. From the molecular biology of prolactin and its receptor to the lessons learned from knockout mice models. Genet Anal 1999; 15: 189-201.

[87] Sorenson RL, Brelje TC. Differences in the regulation of pancreatic islets by prolactin, growth hormone and placental lactogen. In: Horseman N, Ed. Prolactin. Boston: Kluwer 2001; pp. 297-316.

[88] Nielsen JH, Galsgaard ED, Moldrup A, et al. Regulation of $\beta$-cell mass by hormones and growth factors. Diabetes 2001; 50: S25-9.

[89] Fleenor D, Petryk A, Driscoll P, et al. Constitutive expression of placental lactogen in pancreatic beta cells: effects on cell morphology, growth, and gene expression. Pediatr Res 2000; 47: 136-42.

[90] Vasavada RC, Garcia-Ocana A, Zawalich WS, et al. Targeted expression of placental lactogen in the beta cells of transgenic mice results in beta cell proliferation, islet mass augmentation and hypoglycemia. J Biol Chem 2000; 275: 15399-406.

[91] Buckley AR. Prolactin, a lymphocyte growth and survival factor. Lupus 2001; 10: 684-90. 
[92] Fernandez ML, Iglesias MM, Biron VA, et al. Protective effect of prolactin and placental lactogen on NO-induced $\mathrm{Nb} 2$ lymphoma cell apoptosis. Arch Biochem Biophys 2003; 416: 249-56.

[93] Perks CM, Newcomb PV, Grohmann M, et al. Prolactin acts as a potent survival factor against C2-ceramide-induced apoptosis in human granulosa cells. Hum Reprod 2003; 18: 2672-7.

[94] Weinhaus AJ, Bhagroo NV, Brelje TC, et al. Dexamethasone counteracts the effect of prolactin on islet function: implications for islet regulation in late pregnancy. Endocrinology 2000; 141: 138493.

[95] Yamamoto T, Ricordi C, Mita A, et al. Beta-cell specific cytoprotection by prolactin on human islets. Transplant Proc 2008; 40: 382-3.

[96] Bordin S, Amaral ME, Anhê GF, et al. Prolactin-modulated gene expression profiles in pancreatic islets from adult female rats. Mol Cell Endocrinol 2004; 220: 41-50.

[97] Sekine N, Fukumoto S, Ishikawa T, et al. GH inhibits interferongamma-induced signal transducer and activator of transcription-1 activation and expression of the inducible isoform of nitric oxide synthase in INS-1 cells. Endocrinology 2001; 142: 3909-16.

[98] Jensen J, Galsgaard ED, Karlsen AE, et al. STAT5 activation by human GH protects insulin-producing cells against interleukin1 beta, interferon-gamma and tumour necrosis factor-alpha-induced apoptosis independent of nitric oxide production. J Endocrinol 2005; $187: 25-36$

[99] Brelje TC, Scharp DW, Lacy PE, et al. Effect of homologous placental lactogens, prolactins, and growth hormones on islet B-cell division and insulin secretion in rat, mouse, and human islets: implication for placental lactogen regulation of islet function during pregnancy. Endocrinology 1993; 132: 879-87.

[100] Atwater I, Gondos B, DiBartolomeo R, et al. Pregnancy hormones prevent diabetes and reduce lymphocytic infiltration of islets in the NOD mouse. Ann Clin Lab Sci 2002; 32: 87-92.

[101] Stuart KA, Riordan SM, Lidder S, et al. Hepatocyte growth factor/scatter factor-induced intracellular signalling. Int $\mathrm{J}$ Exp Pathol 2000; 81: 17-30.

[102] Furge KA, Zhang YW, Vande Woude GF. Met receptor tyrosine kinase: enhanced signaling through adapter proteins. Oncogene 2000; 19: 5582-9.

[103] Miller M, Leonard EJ. Mode of receptor binding and activation by plasminogen-related growth factors. FEBS Lett 1998; 429: 1-3.

[104] Beattie GM, Rubin JS, Mally MI, et al. Regulation of proliferation and differentiation of human fetal pancreatic islet cells by extracellular matrix, hepatocyte growth factor, and cell-cell contact. Diabetes 1996; 45: 1223-8.

[105] Hayek A, Beattie GM, Cirulli V, et al. Growth factor/matrixinduced proliferation of human adult beta-cells. Diabetes 1995; 44: 1458-60.

[106] Otonkoski T, Beattie GM, Rubin JS, et al. Hepatocyte growth factor/scatter factor has insulinotropic activity in human fetal pancreatic cells. Diabetes 1994; 43: 947-53.

[107] Gahr S, Merger M, Bollheimer LC, et al. Hepatocyte growth factor stimulates proliferation of pancreatic beta-cells particularly in the presence of subphysiological glucose concentrations. J Mol Endocrinol 2002; 28: 99-110.

[108] Garcia-Ocaña A, Takane KK, Syed MA, et al. Hepatocyte growth factor overexpression in the islet of transgenic mice increases beta cell proliferation, enhances islet mass, and induces mild hypoglycemia. J Biol Chem 2000; 275: 1226-32.

[109] Garcia-Ocaña A, Vasavada RC, Cebrian A, et al. Transgenic overexpression of hepatocyte growth factor in the beta-cell markedly improves islet function and islet transplant outcomes in mice. Diabetes 2001; 50: 2752-62.

[110] Kim MS, Kim JW, Sun C, et al. Induction of efficient differentiation and survival of porcine neonatal pancreatic cell clusters using an EBV-based plasmid expressing HGF. J Biochem 2008; 143: 497-503.

[111] Fiaschi-Taesch NM, Berman DM, Sicari BM, et al. Hepatocyte growth factor enhances engraftment and function of nonhuman primate islets. Diabetes 2008; 57: 2745-54.

[112] Garcia-Ocaña A, Takane KK, Reddy VT, et al. Adenovirusmediated hepatocyte growth factor expression in mouse islets improves pancreatic islet transplant performance and reduces beta cell death. J Biol Chem 2003; 278: 343-51.

[113] Santangelo C, Matarrese P, Masella R, et al. Hepatocyte growth factor protects rat RINm5F cell line against free fatty acid-induced apoptosis by counteracting oxidative stress. J Mol Endocrinol 2007; 38: 147-58.

[114] González-Pertusa JA, Dubé J, Valle SR, et al. Novel pro-apoptotic effect of hepatocyte growth factor: Synergy with palmitate to cause pancreatic beta cell apoptosis. Endocrinology 2010; 151: 1487-98.

[115] Dai C, Li Y, Yang J, et al. Hepatocyte growth factor preserves beta cell mass and mitigates hyperglycemia in streptozotocin-induced diabetic mice. J Biol Chem 2003; 278: 27080-7.

[116] Park MK, Kim DK, Lee HJ. Adenoviral mediated hepatocyte growth factor gene attenuates hyperglycemia and beta cell destruction in overt diabetic mice. Exp Mol Med 2003; 35: 494500.

[117] Lopez-Talavera JC, Garcia-Ocaña A, Takane KK, et al. Hepatocyte growth factor gene therapy, for pancreatic islets in diabetes: Reducing the minimal islet transplant mass required in a glucorcorticoid-free rat model of allogeneic portal vein islet transplantation. Endocrinology 2004; 145: 467-74.

[118] Jones, JI, Clemmons, DR. Insulin-like growth factors and their binding proteins: Biological actions. Endocr Rev 1995; 16: 3-34.

[119] LeRoith, D. Insulin-like growth factors. In Seminars in Medicine of the Beth Israel Deaconess Medical Center 1997; vol. 336: pp. 63340.

[120] Nakae J, Kido Y, Accili D. Distinct and overlapping functions of insulin and IGF-I receptors. Endocr Rev 2001; 22: 818-35.

[121] Fehmann HC, Jehle P, Markus U, et al. Functional active receptors for insulin-like growth factors-I (IGF-I) and IGF-II on insulin-, glucagon-, and somatostatin-producing cells. Metabolism 1996; 45: 759-66.

[122] Vasavada RC, Gonzalez-Pertusa JA, Fujinaka Y, et al. Growth factors and beta cell replication. Int J Biochem Cell Biol 2006; 38: 931-50.

[123] Hogg J, Han VK, Clemmons DR, et al. Interactions of nutrients, insulin-like growth factors (IGFs) and IGFbinding proteins in the regulation of DNA synthesis by isolated fetal rat islets of Langerhans. J Endocrinol 1993; 138: 401-12.

[124] Petrik J, Pell JM, Arany E, et al. Overexpression of insulin-like growth factor-II in transgenic mice is associated with pancreatic islet cell hyperplasia. Endocrinology 1999; 140: 2353-63.

[125] George M, Ayuso E, Casellas A, et al. Beta cell expression of IGFI leads to recovery from type 1 diabetes. J Clin Invest. 2002; 109: 1153-63.

[126] Ilieva A, Yuan S, Wang RN, et al. Pancreatic islet cell survival following islet isolation: the role of cellular interactions in the pancreas. J Endocrinol 1999; 161: 357-64.

[127] Robitaille R, Dusseault J, Henley N, et al. Insulin-like growth factor II allows prolonged blood glucose normalization with a reduced islet cell mass transplantation. Endocrinology 2003; 144: $3037-45$.

[128] Navarro-Tableros V, Sánchez-Soto MC, García S, et al. Autocrine regulation of single pancreatic beta-cell survival. Diabetes 2004; 53:2018-23.

[129] Muller D, Jones PM, Persaud SJ. Autocrine anti-apoptotic and proliferative effects of insulin in pancreatic beta-cells. FEBS Lett 2006; 580: 6977-80.

[130] Johnson JD, Bernal-Mizrachi E, Alejandro EU, et al. Insulin protects islets from apoptosis via Pdx1 and specific changes in the human islet proteome. Proc Natl Acad Sci USA 2006; 103: 19575 80 .

[131] Cahuana GM, Tejedo JR, Hmadcha A, et al. Nitric oxide mediates the survival action of IGF-1 and insulin in pancreatic beta cells. Cell Signal 2008; 20: 301-10.

[132] Assmann A, Ueki K, Winnay JN, et al. Glucose effects on beta-cell growth and survival require activation of insulin receptors and insulin receptor substrate 2. Mol Cell Biol 2009; 29: 3219-28.

[133] Zhi-hong C, Tang LI, Zong-bo C, et al. Prevention of beta cell dysfunction and apoptosis by adenoviral gene transfer of rat insulin-like growth factor 1. Chin Med J 2009; 122: 2159-64.

[134] Avram D, Ranta F, Hennige AM, et al. IGF-1 protects against dexamethasone-induced cell death in insulin secreting INS-1 cells independent of AKT/PKB phosphorylation. Cell Physiol Biochem 2008; 21: 455-62.

[135] Srinivasan S, Ohsugi M, Liu Z, et al. Endoplasmic reticulum stressinduced apoptosis is partly mediated by reduced insulin signaling through phosphatidylinositol 3-kinase/Akt and increased glycogen synthase kinase-3beta in mouse insulinoma cells. Diabetes 2005; 54: $968-75$. 
[136] Mabley JG, Belin V, John N, et al. Insulin-like growth factor I reverses interleukin-1beta inhibition of insulin secretion, induction of nitric oxide synthase and cytokine-mediated apoptosis in rat islets of Langerhans. FEBS Lett 1997; 417: 235-8.

[137] Harrison M, Dunger AM, Berg S, et al. Growth factor protection against cytokine-induced apoptosis in neonatal rat islets of Langerhans: role of Fas. FEBS Lett 1998; 435: 207-10.

[138] Petrik J, Arany E, McDonald TJ, et al. Apoptosis in the pancreatic islet cells of the neonatal rat is associated with a reduced expression of insulin-like growth factor II that may act as a survival factor. Endocrinology 1998; 139: 2994-3004.

[139] Hill DJ, Petrik J, Arany E, et al. Insulin-like growth factors prevent cytokine-mediated cell death in isolated islets of Langerhans from pre-diabetic non-obese diabetic mice. J Endocrinol 1999; 161: 15365 .

[140] Giannoukakis N, Mi Z, Rudert WA, et al. Prevention of beta cell dysfunction and apoptosis activation in human islets by adenoviral gene transfer of the insulin-like growth factor I. Gene Ther 2000; 7 : 2015-22.

[141] Castrillo A, Bodelón OG, Boscá L. Inhibitory effect of IGF-I on type 2 nitric oxide synthase expression in Ins-1 cells and protection against activation-dependent apoptosis: involvement of phosphatidylinositol 3-kinase. Diabetes 2000; 49: 209-17.

[142] Chen W, Salojin KV, Mi QS, et al. Insulin-like growth factor (IGF)-I/IGF-binding protein-3 complex: therapeutic efficacy and mechanism of protection against type 1 diabetes. Endocrinology 2004; 145: 627-38.
[143] Robertson K, Lu Y, De Jesus K, et al. A general and islet cellenriched overexpression of IGF-I results in normal islet cell growth, hypoglycemia, and significant resistance to experimental diabetes. Am J Physiol Endocrinol Metab. 2008; 294: E928-38.

[144] Casellas A, Salavert A, Agudo J, et al. Expression of IGF-I in pancreatic islets prevents lymphocytic infiltration and protects mice from type 1 diabetes. Diabetes 2006; 55: 3246-55.

[145] Kodama K, Shimada A, Funae O, et al. Insulin-like growth factor-1 (IGF-1)-derived peptide protects against diabetes in NOD mice. Autoimmunity 2004; 37: 481-7.

[146] Kaino Y, Hirai H, Ito T, et al. Prevention of diabetes in non-obese diabetic (NOD) mice by short-term and high-dose IGF-I treatment. J Pediatr Endocrinol Metab 1998; 11: 267-72.

[147] Hill DJ, Strutt B, Arany E, et al. Increased and persistent circulating insulin-like growth factor II in neonatal transgenic mice suppresses developmental apoptosis in the pancreatic islets. Endocrinology 2000; 141: 1151-7.

[148] Lu Y, Herrera PL, Guo Y, et al. Pancreatic-specific inactivation of IGF-I gene causes enlarged pancreatic islets and significant resistance to diabetes. Diabetes 2004; 53: 3131-41.

[149] Duvillié B, Currie C, Chrones T, et al. Increased islet cell proliferation, decreased apoptosis, and greater vascularization leading to beta-cell hyperplasia in mutant mice lacking insulin. Endocrinology 2002; 143: 1530-7.

[150] Ueki K, Okada T, Hu J, et al. Total insulin and IGF-I resistance in pancreatic beta cells causes overt diabetes. Nat Genet 2006; 38: 583-8.

(C) Kondegowda et al.; Licensee Bentham Open.

This is an open access article licensed under the terms of the Creative Commons Attribution Non-Commercial License (http://creativecommons.org/licenses/by$\mathrm{nc} / 3.0 /$ ) which permits unrestricted, non-commercial use, distribution and reproduction in any medium, provided the work is properly cited. 